\title{
Chemical Weapons Research on Soldiers and Concentration Camp Inmates in Nazi Germany
}

\author{
Florian Schmaltz
}

\begin{abstract}
In 1944 and 1945 scientists and physicians in the Allied military intelligence gathered evidence on the criminal human experiments with chemical weapons conducted on inmates of the Nazi concentration camps in Sachsenhausen, Natzweiler, and Neuengamme during World War II. Some of the experiments were judged during the Nuremberg Medical Trial (Case I) and French military tribunals at Metz and Lyon after liberation. Based on this evidence and on further archival sources, this paper will examine the preconditions and settings of these experiments, the perpetrators involved, and what is known about their purpose and outcome. Furthermore, the paper will raise the question if and how the experiments in the concentration camps were linked to other experiments conducted in Nazi Germany for the Wehrmacht at military research establishments such as the Gas Protection Laboratory (Heeresgasschutzlaboratorium) in Spandau, the Militärärztliche Akademie, the Heeresversuchsstelle Raubkammer, or by universities. The paper will focus on experiments with chemical agents in German concentration camps and analyze how rivalry and division of labor between the military and the SS in human experimentation with chemical agents went hand in hand.
\end{abstract}

\section{Organizational Structures of Chemical Warfare Research in Germany}

Chemical warfare research in military and academic contexts is generally an issue of secrecy. It encompasses screening, identification of potential chemical agents suitable for use as weapons, means and methods for their large-scale industrial production, storage and deployment, as well as defensive research in toxicology on animals and humans. It also includes possible medical prophylaxis and treatments, as well as measures and technologies for detecting chemical agents and protecting soldiers and civilians against the severe injuries and health risks involved. In contrast to other fields of scientific research, most of the results on chemical warfare

\footnotetext{
F. Schmaltz ( $\square)$

Max Planck Institute for the History of Science, Berlin, Germany

e-mail: schmaltz@mpiwg-berlin.mpg.de

(C) The Author(s) 2017

B. Friedrich et al. (eds.), One Hundred Years of Chemical Warfare: Research,

Deployment, Consequences, DOI 10.1007/978-3-319-51664-6_13
} 
issues have remained unpublished. In the case of Nazi Germany, military agencies and private companies involved in the research, development, and production of chemical weapons systematically destroyed their records from Fall 1944. Since the intention was to avoid written evidence, orders were given only orally so that events remained undocumented. This holds even truer for the human experiments conducted in concentration camps. The determination to cover up and destroy evidence of war crimes and crimes against humanity by the perpetrators in Nazi Germany makes it difficult to establish the historical facts. Uncertainties will remain.

The utilization of hydrogen cyanide (known under the trademark Zyklon B) or carbon monoxide as gasses used in the destruction of the European Jews, Sinti, and Roma in the extermination camps at Auschwitz, Majdanek, Sobibor, Treblinka, and other places, or the murder of invalids and handicapped persons at these killing centers will not be discussed in this paper. Both compounds were not suitable for extra mural deployment as war gas because of their fugacity. ${ }^{1}$

In the Weimar Republic, research and development of chemical weapons had been organized in a covert network of smaller dislocated working groups and laboratories in Germany and abroad by means of a secret collaboration between the Reichswehr and the Red Army (Müller 1985; Brauch and Müller 1985; Groehler 1992; Krause and Mallroy 1993; Schmaltz 2005).

After the Nazis had seized power in January 1933, the research and development of chemical weapons became high priority in the context of the armament policy of the new regime. Efforts were made to establish a greater research infrastructure with more than 1000 employees working in three army-operated chemical warfare research centers. The largest institution by far became the testing ground and laboratories of the Wehrmacht at Raubkammer near Munster with an average of 500 employees, peaking at 800 in 1944 (Mills 1945, 9). The second in size was the so-called Gas Protection Laboratory (Heeresgasschutzlaboratorium) installed by the Army Ordnance Office (Heereswaffenamt, Wa Prüf 9) in the Citadel Spandau, which insulated and shielded its 450 employees from the public. Despite its name, the Gas Protection Laboratory also conducted offensive research on new chemical agents. In addition, the Gas Protection Office of the Army Ordnance Office (Wa Prüf 9) was established in Berlin with an average of 143 employees, peaking at 200 in 1944 (Mills 1945, 9) (Table 1).

The Military Medical Academy (Militärärztliche Akademie) in Berlin reopened in October 1934 in the building of the Kaiser Wilhelm Academy which had been closed consistent with the Treaty of Versailles (Neumann 2005, 70). There, the Department of Pharmacology and Military Toxicology (Institut für Pharmakologie und Wehrtoxikologie), headed by Otto Muntsch and Wolfgang Wirth, played an

\footnotetext{
${ }^{1}$ For the history of Zyklon B and the gas chambers in German concentration camps, see Szöllösi-Janze (1994), Ebbinghaus (1998), Kalthoff and Werner (1999), Joly (2000), Hayes (2004, 272-300), Morsch and Perz (2011), Trunk (2011).
} 
Table 1 Organization of German chemical warfare research and development ${ }^{\mathrm{a}}$

\begin{tabular}{|c|c|c|c|}
\hline $\begin{array}{l}\text { Heeresversuchsstelle (Army } \\
\text { experimental station), } \\
\text { Raubkammer (Munster) }\end{array}$ & $\begin{array}{l}\text { Heereswaffenamt (Army } \\
\text { ordnance office) -Wa Prüf 9, } \\
\text { Berlin (Group 1-12) }\end{array}$ & \multicolumn{2}{|c|}{$\begin{array}{l}\text { Heeresgasschutzlaboratorium (Army } \\
\text { gas protection laboratory), } \\
\text { Spandau }^{\mathrm{b}}\end{array}$} \\
\hline & & Dept. & Research field \\
\hline R I: Field trials & 1: Organization and direction & F1 & Chemical synthesis \\
\hline R II: Chemical analysis & 2: Gas defense & \multirow[t]{7}{*}{ F2 } & Analytical chemical \\
\hline $\begin{array}{l}\text { R III: Decontamination and } \\
\text { detection }\end{array}$ & $\begin{array}{l}\text { 3: Decontamination and gas } \\
\text { protection }\end{array}$ & & Lab. 1 Polarimetry \\
\hline $\begin{array}{l}\text { R IV: Vehicles and } \\
\text { workshops }\end{array}$ & 4: Mechanical & & Lab. 2 Sarin and tabun \\
\hline 5: Extra mural research & 5: Extra mural research & & $\begin{array}{l}\text { Lab. } 3 \text { Examination of loot, } \\
\text { HCN determination, } \\
\text { ampoules and storage }\end{array}$ \\
\hline 6: Gas and smoke weapons & 6: Gas and smoke weapons & & Lab. 4 Mustard (derivates) \\
\hline 7: Testing field trials & 7: Testing field trials & & Lab. 5 Chamber trials \\
\hline $\begin{array}{l}\text { 8: CW Manufacture } \\
\text { (technology) }\end{array}$ & $\begin{array}{l}\text { 8: CW Manufacture } \\
\text { (technology) }\end{array}$ & & Lab. 6 Sarin research \\
\hline 9: Finance & 9: Finance & \multirow[t]{6}{*}{ F 3} & Microchemistry \\
\hline 10: Incendiaries & 10: Incendiaries & & $\begin{array}{l}\text { Microchemical and } \\
\text { physicochemical }\end{array}$ \\
\hline 11: Patents & 11: Patents & & Physical measurements \\
\hline 12: Veterinary & 12: Veterinary & & Smoke \\
\hline \multirow[t]{17}{*}{ 13: Intelligence } & 13: Intelligence & & \begin{tabular}{|l}
$\begin{array}{l}\text { Adsorption and desorption of } \\
\text { charcoal }\end{array}$ \\
\end{tabular} \\
\hline & & & $\begin{array}{l}\text { Molecular weight } \\
\text { measurements }\end{array}$ \\
\hline & & F 4 & $\begin{array}{l}\text { Measurements of } \\
\text { concentrations on films }\end{array}$ \\
\hline & & F 5 & Library \\
\hline & & IIL & Individual \\
\hline & & IIIL & Collective protection \\
\hline & & IIIaL & Filter units \\
\hline & & IIIbL & Detection and recognition \\
\hline & & IIIcL & $\begin{array}{l}\text { Decontamination/CW } \\
\text { munitions }\end{array}$ \\
\hline & & IVL & Mechanical \\
\hline & & VWL & Physiological chemical \\
\hline & & \multirow[t]{5}{*}{ VIaL } & Ground contamination \\
\hline & & & Lab. 1: Dust \\
\hline & & & Lab. 2: Organic chemicals \\
\hline & & & Lab. 3: Organic chemicals \\
\hline & & & Lab. 4: Mustard \\
\hline & & VIbL & $\begin{array}{l}\text { Smoke and thermal } \\
\text { generators }\end{array}$ \\
\hline
\end{tabular}


Table 1 (continued)

\begin{tabular}{l|l|l|l}
\hline $\begin{array}{l}\text { Heeresversuchsstelle (Army } \\
\text { experimental station), } \\
\text { Raubkammer (Munster) }\end{array}$ & $\begin{array}{l}\text { Heereswaffenamt (Army } \\
\text { ordnance office)_Wa Prüf 9, } \\
\text { Berlin (Group 1-12) }\end{array}$ & $\begin{array}{l}\text { Heeresgasschutzlaboratorium (Army } \\
\text { gas protection laboratory), } \\
\text { Spandaub }\end{array}$ \\
\hline \multicolumn{2}{|l|}{} & Dept. & Research field \\
\hline & VIcL & $\begin{array}{l}\text { Small scale development of } \\
\text { shells-HE tests for shells }\end{array}$ \\
\cline { 3 - 4 } & VIdL & Meteorology \\
\cline { 3 - 4 } & VIIL & $\begin{array}{l}\text { Toxicological Institute } \\
\text { (animal- and human } \\
\text { experiments) }\end{array}$ \\
\hline & VIIIL & $\begin{array}{l}\text { Semi-technical scale plant } \\
\text { chemical storage }\end{array}$ \\
\hline
\end{tabular}

${ }^{a}$ A. K. Mills, Investigations of Chemical Warfare Installations in the Munsterlager area, including Raubkammer. CIOS File No. XXXI-86, (London SHAEF Combined Intelligence Objectives Sub-Committee-G-2 Division: 1945), Tables I-III on pp. 27-33

'Ibid., Table II, pp. 29-31

important role in chemical warfare research. ${ }^{2}$ The Military Medical Academy and the Army Ordnance Office (Wa Prüf 9) established a network of outposts at universities in Marburg, Munster, Giessen, Würzburg, Greifswald, and at the Academy of Medicine at Danzig (Oehler-Klein and Neumann 2004; Schmaltz 2006b; Eberle 2015, 505-524). Furthermore, several institutes of the Kaiser Wilhelm Society were also included in this network after 1933 (Schmaltz 2005, 2009).

While the hegemony of military institutions in chemical warfare research remained dominant until the end of World War II, from 1942 on the SS tried to assert itself against the Wehrmacht through its research organization, the SS-Ahnenerbe. Initially founded as a registered association in 1935, the SS-Ahnenerbe was incorporated between the end of March and April 1942 into the Personal Staff of the Reich leader of the SS, Heinrich Himmler (Kater 1997, 11, 302, 463; Schleiermacher 1988, 79-83; Reitzenstein 2014, 34). In July 1942, the SS-Ahnenerbe established the Institute for Applied Military Research (Institut für wehrwissenschaftliche Zweckforschung), with a special branch headed by the anatomist August Hirt at the "Reichsuniversität Straßburg" to foster chemical warfare research (Schmaltz 2005, 530). With its direct link to Himmler, the SS-Ahnenerbe had privileged access to concentration camp inmates as subjects for human experimentation. From May 1944 all SS and police agencies had to apply to Himmler for personal authorization to conduct human experiments in concentration camps. Applications had to be submitted to the Reichsarzt-SS, substantiating scientific objectives as well as the required number of prisoners and duration of experiments. ${ }^{3}$ There is no doubt that military experts were informed about specific human experiments with chemical

\footnotetext{
${ }^{2}$ For Muntsch's career, see Kästner and Hahn (1994), Neumann (2005, 83).

${ }^{3}$ Himmler (Reichsführer SS), copy, May 15, 1944, Bundesarchiv Berlin (BArch), R 26 III/729, fol. 36; Schmaltz (2005, 176-177), Hahn (2008, 480).
} 
agents in concentration camps. Some of the military experts were also involved in their preparation and evaluation.

In addition to military laboratories and academic research institutions, chemical warfare research was also undertaken in the laboratories of private chemical companies. However, chemical warfare research in private companies such as I.G. Farbenindustrie on nerve agents apparently only involved animals and self-experiments on humans. Regarding the military, there are no documents available that give evidence of forced human experiments in industrial research laboratories (Schmaltz 2005, 455-459).

\section{Chemical Weapons Research on Humans in Military and Academic Institutions}

New compounds suitable for chemical warfare were regularly first tested on animals and humans at the Military Medical Academy in several gas chambers with a volume of 2-3 cubic meters before toxicological studies were conducted in the 10,30 , and $100 \mathrm{~m}^{3}$ gas chambers of department VII L, or the larger gas chambers of the Gas Protection Laboratory at Spandau with 250 and up to $1000 \mathrm{~m}^{3}$ (Mills 1945, 9-10). The human experiments were conducted in self-experiments by the scientists and on soldiers, officer cadets, members of student companies (Studentenkompanien), and convalescent companies (Genesungskompanien). These experiments covered toxicological evaluations, defensive protection technologies (gas masks and protection gear), and the treatment of injuries caused by chemical agents (Schultz 2001; Kopke and Schultz 2001, 242-246; Baader 2002; Neumann 2005, 288-298; Woelk 2003, 283). The participants from the military knew that the experiments implied health risks. Officially, military test persons participated voluntarily, but we can assume that peer pressure as well as compensation offered of between 5 and 100 Reichsmarks may have been an incentive (Kopke and Schultz 2001, 243-244; Neumann 2005, 289-290). Apart from the pain experienced during the actual experiments, the long-term health problems and consequential suffering are well documented for a number of cases (Spiegelberg et al. 1961). The publicist Ernst Klee claimed that on several occasions, death row inmates at Plötzensee Prison were transferred to the Gas Protection Laboratory and subjected without their consent to experiments with chemical agents (Klee 1997, 272-273). ${ }^{4}$ This statement is based on only one testimony of a hearsay witness, who did not accompany the prisoners to the alleged experimentation. ${ }^{5}$

\footnotetext{
${ }^{4}$ Affidavit of the former juridical officer Affidavit Walter Strelow, November 27, 1946, NG-405, in Dörner et al. (2000b, microfiche 4/7764-7766).

${ }^{5}$ For a critical review of Klee's (mis)interpretation, see Kopke and Schultz (2001, 245-246), Neumann $(2005,295-296)$.
} 
Nonetheless, the experiments in the military institutions remained ethically and legally dubious. The "Regulations Concerning New Therapy and Human Experimentation," issued by the Reich Ministry of Interior in 1931 prohibited experimentation "in all cases where consent has not been given." To date, no sources on any internal discussions concerning ethical frameworks or the implementation of regulations for human experiments in military institutions during the Nazi era have been found. As the historian Ulf Schmidt has emphasized, military researchers either ignored the 1931 guidelines or were unaware of their existence (Schmidt 2013, 236; Roelcke 2017). In many cases, it is unclear if sufficient animal testing had taken place prior to the human experiments with chemical agents. In contrast to this complete lack of any institutionalized regulation of ethical issues concerning human experiments, the Nazi regime established such regulations for animal experiments in line with the animal protection law of 1933. In spring 1939, the medical service of the Wehrmacht (Sanitätsinspektion) restricted animal experiments to scientific laboratories, and a number of military institutes established frequent expert inspections. ${ }^{7}$ The German attack against Poland further weakened the limitations set by medical ethics. German soldiers suffering from battle wounds and infections and civilians affected psychologically by Allied air raids, along with chemical warfare experts and physicians all radicalized their approach to exploiting vulnerable concentration camp inmates as subjects of human experiments. During World War II, human experiments dealing with agents suitable for chemical warfare were conducted in the concentration camps at Sachsenhausen in 1939, at Natzweiler from 1942 to 1944, and at Neuengamme in 1944.

Rumors about another series of human experiments with war gasses on inmates of a sub-camp of the concentration camp Groß-Rosen, who were forced to work in the nerve gas factory at Dyhernfurth near Breslau where tabun was produced and filled in shells from 1942 onward, are not confirmed by available sources. There is no doubt, however, that camp inmates were forced to work at Dyhernfurth in the extremely dangerous tabun production and filling stations with only insufficient protection, and consequently suffered severe damage to their health (Czernik 1974; Groehler 1989, 245-248; Ebbinghaus 1999, 185-186). Accidents-some of them fatal-occurred frequently, even among the German workers (Jones 1945, 10). While eyewitness accounts confirm that emergency treatments with atropine were used, no evidence has been established so far that camp inmates were subjected to standardized human experiments in a controlled manner. ${ }^{8}$

\footnotetext{
${ }^{6}$ Rundschreiben des Reichsministers des Inneren vom 28.2.1931: Richtlinien für die neuartige Heilbehandlung und für die Vornahme wissenschaftlicher Versuche am Menschen 1931, see Schmidt (2013, 236), Sass (1983), Grodin (1992, 129-132).

${ }^{7}$ Waldmann (OKW B 49 OKH/AHA S In II) to Militärärztliche Akademie (copy), April 29, 1939; Müller (OKW B 49 OKH/AHA S.In II) to Militärärztliche Akademie (addendum), May 31, 1939, Bundesarchiv-Militärarchiv (BA-MA) Freiburg, RH 12-23/1740.

${ }^{8}$ The former prisoner Tadeusz Karol, who survived the Dyhernfurth concentration camp, testified that he was ordered to enter the filling station without gas protection gear in order to examine a possible contamination with tabun. Karol collapsed after being injured by the nerve agent. An
} 


\section{Experiments in Concentration Camps}

\subsection{Sachsenhausen}

On September 8, 1939, one week after the invasion of the Wehrmacht in Poland, Polish troops who were withdrawing accidently used sulphur mustard mines instead of regular explosives to blow up a bridge at Jaslo. This incidence caused mustard gas injuries to 14 German soldiers, two of which were fatal. The incident immediately led to an investigation by German chemical warfare experts. ${ }^{9}$ In direct response to this incident, the Military Medical Academy and the SS initiated several series of tests to evaluate possible treatments of skin wounds caused by sulphur mustard gas. At least two series were conducted in the concentration camp at Sachsenhausen on a total of 31 prisoners. The wounds were treated with different drugs: (1) Freskan (code name F 1000 and F 1001), a powder produced by the company Dr. Fresenius (Bad Homburg) to cure skin burns; (2) the Holzmannsche-Lost-Heilmittel; and (3) probably Thiosept, an ointment based on sulphurous shale oil (Figs. 1 and 2, Table 2).

For the first series of experiments, Reichsarzt SS Dr. Ernst Grawitz ordered SS physician Dr. Hugo-Heinz Schmick, then in charge of the surgical ward at Sachsenhausen concentration camp, to conduct the experiments. ${ }^{10}$ Schmick worked together with camp physician Dr. Walter Sonntag. On October 13, 1939 sulphur mustard was applied to the upper arms of 23 inmates. ${ }^{11}$ According to an account by the former political prisoner Hans Kargl, ${ }^{12}$ he and four other inmates from his barrack (Theuer, Steinmeyer, Hahn, and Grunert) were treated with a "yellow liquid" which was smeared in a radius of about $3 \mathrm{~cm}$ on both upper arms causing blistering,

\footnotetext{
(Footnote 8 continued)

atropine injection saved his life. See OK Wroclaw, Ds 1/68, pp. 225-227 and 244-247, eyewitness testimony by Tadeusz Karol, cited after Witkowski and Rudy (1987, 135-136). I am grateful to Esther Chen (Max Planck Institute for the History of Science) for her helpful advice and explanation concerning the Polish publication.

${ }^{9}$ Wolfgang Wirth (Heereswaffenamt Gasschutzabteilung): Bericht über die Verwendung von Lostminen durch die Polen bei Jaslo am 8.9.1939, September 16, 1939, BA-MA Freiburg, Bestandsergänzungsfilm WF-01/20871 (National Archives Washington, DC, Microfilm, T-77, reel 876, frames 5624376-5624396); Martinetz (1996, 167-168), Gellermann (1986, 135-136).

${ }^{10}$ Hugo Heinz Schmick (1909-1982) became a member of the NSDAP in August 1933 (No. 3681138) and of the SS (No. 84693) in May 1933. From June 1939 he was assigned to the concentration camp Sachsenhausen where he was ordered to establish the surgical ward. SSO Akte Hugo-Heinz Schmick, geb. 30.3.1909, BArch, VBS 286/6400039545; NSDAP-Ortsgruppenkartei Hugo-Heinz Schmick, geb. 30.3.1909, BArch, VBS 250. Vernehmungsprotokoll von Dr. Hugo Schmick durch den Untersuchungsrichter beim Landgericht Duisburg, July 21, 1951, Archives of the Memorial and Museum Sachsenhausen (AMMS), JD 1/22, pp. 19-22; Kopke and Schultz (2001, 247).

${ }^{11}$ Dr. Sonntag, Abschlußbericht über die mit L. am 13. Oktober 1939 geimpften 23 Fälle, December 22, 1939 (=NO-198), BArch, NS 19/1582, fol. 2.

${ }^{12}$ For the biography of Hans Kargl (1884-1960) see Ley and Morsch (2007, 335-337).
} 
Fig. 1 Walter Sonntag (Courtesy of the Bundearchiv R 9361-III/195957)

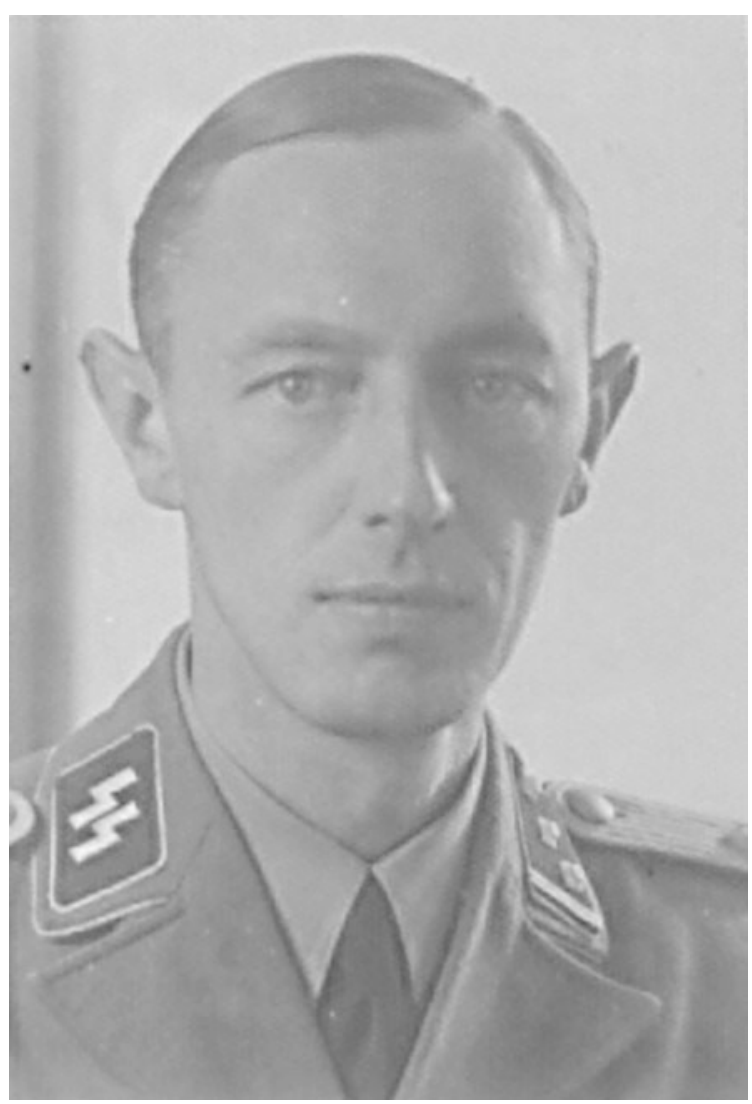

open wounds. ${ }^{13}$ These were then treated with an ointment (probably Thiosept) and Freskan. According to Kragl, the treatment caused violent pain. ${ }^{14}$ Assisted by the orderly Fritz Langheinrich, the wounds and the healing process were documented in medical records, on film, and photographs. ${ }^{15}$ In the second series of experiments, eight prisoners were treated with mustard gas on both arms. After three days, the blisters were opened to infect the wounds of two prisoners with a mixed flora of streptococcus, staphylococcus, and pneumococcus bacteria. Another two of the eight

\footnotetext{
${ }^{13}$ Hans Kargl: Erlebnisniederschrift über die Zeit der Verfolgung und Inhaftierung während des Naziregimes. (Typoskript), undated, AMMS, P3 (Stadtarchiv Hanau, 103/85), fol. 55-56; Kopke and Schultz (2001, 116-117).

${ }^{14} \mathrm{Ibid}$. For the name of the ointment, see Landgerichtsrat Peterek (Untersuchungsgericht Duisburg): Vernehmung von Mathias Mai, December 6, 1950, AMMS, JD 1/22, fol. 6-8.

${ }^{15}$ Wissner (Kriminalpolizei Düsseldorf): Vernehmung von Fritz Langheinrich, November 18, 1949, Archives of the Memorial and Museum Sachsenhausen JD 1/22, fol. 2-5.
} 
Fig. 2 Hugo Heinz Schmick (Courtesy of the Bundesarchiv NSDAP Zentralkartei)

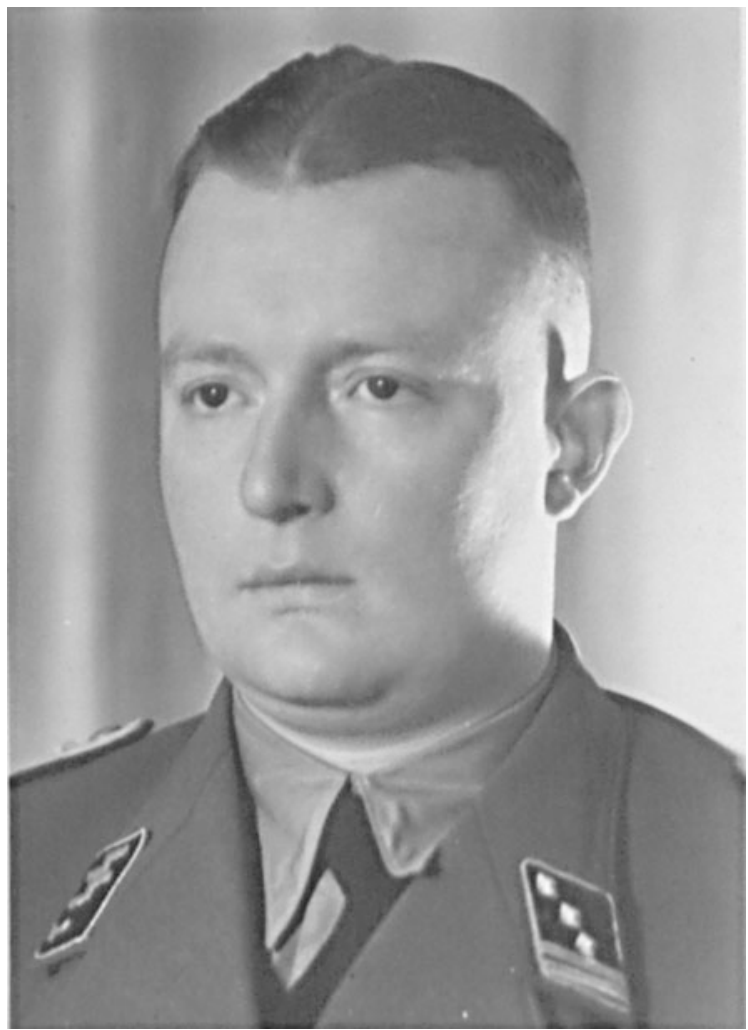

Table 2 Concentration camp Sachsenhausen: mustard gas experiments

\begin{tabular}{|c|c|c|c|}
\hline Time period & Researcher & Objective & Subject \\
\hline \multirow[t]{2}{*}{$\begin{array}{l}13 \text { Oct.-Dec. } \\
1939\end{array}$} & $\begin{array}{l}\text { Walter } \\
\text { Sonntag } \\
\text { Hugo Heinz } \\
\text { Schmick }\end{array}$ & $\begin{array}{l}\text { Therapeutic effect of Freskan } \\
\text { powder }\end{array}$ & \multirow[t]{2}{*}{$\begin{array}{l}23 \text { concentration camp }^{\text {a }} \\
\text { inmates }^{\text {a }}\end{array}$} \\
\hline & $\begin{array}{l}\text { Fritz } \\
\text { Langheinrich }\end{array}$ & Holzman remedy & \\
\hline Dec. 1939 & $\begin{array}{l}\text { Walter } \\
\text { Sonntag } \\
\text { Hugo Heinz } \\
\text { Schmick }\end{array}$ & $\begin{array}{l}\text { Ditto and antiseptic effect on } \\
\text { bacterial infections }\end{array}$ & 8 inmates \\
\hline
\end{tabular}

${ }^{\mathrm{a}}$ The numbers of victims vary. While Sonntag noted in his report that 23 inmates were used, former prisoner Frank Cyranek estimated a number of 28 to 30 prisoners. See Vernehmung von Franz Cyranek, copy, (undated), Archives of the Memorial and Museum Sachsenhausen (hereafter cited as AMMS), JD 1/22, fol. 16 
prisoners received the same treatment on the fourth day. ${ }^{16}$ Some of the wounds reached a size of $7 \times 18 \mathrm{~cm}$. The infected prisoners developed sepsis with high temperatures, shivering, swelling of the glands, and enlarged spleens. ${ }^{17}$ The prisoners' suffering led to the insight that neither Holzmann's remedy nor the Freskan powder had any healing effect on the mustard gas wounds or the infections. ${ }^{18}$ In January 1940 Reichsführer SS Heinrich Himmler was informed about the negative results. ${ }^{19}$ While the experiments of the SS were taking place at the Sachsenhausen concentration camp, the Wehrmacht had also started a series of human experiments investigating the efficacy of Freskan powder F 1000 and F 1001 for the decontamination and therapy of skin lesions caused by mustard gas. ${ }^{20}$ The two chemical war experts who conducted those experiments were Ludwig Lendle and Wolfgang Wirth. Lendle was one of the leading German pharmacologists at the time and since 1936 director of the Institute for Pharmacology at the University Münster. In August 1939 Lendle was ordered on duty to the Institute for Pharmacology and Military Toxicology at the Military Medical Academy. ${ }^{21}$ There he collaborated with the head of this institute, Wolfgang Wirth. ${ }^{22}$

\footnotetext{
${ }^{16}$ SS-Untersturmführer Dr. Sonntag, Vorläufiger Bericht über 8 Fälle von 'Öl-O'-Verätzungen und deren Behandlung mit dem Mittel 'H' bzw. 'F 1001' unter Setzung einer Infektion in 4 der Fälle, December 22, 1939, BArch, NS 19/1582, fol. 4.

${ }^{17}$ Ibid., fol. 5-6.

${ }^{18}$ Ibid., fol. 6 .

${ }^{19}$ Grawitz to Personal Staff RFSS, January 5, 1940, BArch, NS 19/1582, fol. 3. Himmler received the letter on January 16, 1940.

${ }^{20}$ Bericht über die Eignung der Freskanpuder F 1000 und F 1001 zur Entgiftung und Behandlung von Lostschäden der Haut, December 21, 1939, secret, signed Lendle and Wirth, pp. 1-49 and 1 Table, BA-MA Freiburg, RH 12-23/1728.

${ }^{21}$ For Lendle's biography and his activities concerning chemical warfare research, see Schmaltz (2005, 468-470); Lendle, Lebenslauf, January 29, 1945, BArch, R 9361 II, Parteikorrespondenz, Ludwig Lendle, born February 2, 1899; for his postwar career, see Schmidt (1985).

${ }^{22}$ Wolfgang Wirth (1898-1996), studied studied chemistry in Munich and Würzburg and medicine in Berlin. He worked as assistant to Gauss at the University Clinic and as assistant to Werner Haase at the Laboratory for physiological Zoology of the Biologische Reichsanstalt für Land- und Forstwirtschaft. Wirth conducted research on chemical agents during the Weimar Republic in Germany and in the context of the secret collaboration with the USSR on behalf of the Army Ordnance Office. Wirth became a member of the SA in 1933 and the NS-Lehrerbund, the NSV, and the Reichskolonialbund in 1936. From April 1936 until January1938 he worked for the Heereswaffenamt Wa Prüf 9 (Army Ordnance Office, Chemical Warfare Department) and changed in February 1938 to the Militärärztliche Akademie (Military Medical Academy), where he headed the Pharmacological Institute. From June 1941 Wirth was the provisional commander and from August 1942 to August 1943 the commander of the Lehrgruppe C-Forschungsgruppe (Teaching Group C/Research Group) at the Military Medical Academy. Wirth was arrested in June 1945 and interned in Nuremberg during the Doctors Trial between December 1946 and August 1947. In 1948 he entered the Pharmacological Department of the Farbenfabriken Bayer A.G. in Wuppertal which he headed from 1954 until his retirement in 1963. See Military Government of Germany. Fragebogen Wolfgang Wirth, June, 14, 1946, pp. 19-28; Lebenslauf Wolfgang Wirth, 30.8.1944, and Lebenslauf 1.6.1944, US Army - Freedom of Information/Privacy Office-Fort G. Meade, Investigative Records Repository, file Wolfang Wirth. For Wirth's biography, see Kopke and
} 
Lendle and Wirth conducted a series of human experiments on 23 officer cadets (Fähnriche) at the Military Medical Academy. They began by smearing one gram of LOST on two parts of the underarm of the soldiers. No decontamination measures followed. The dose applied was strong enough to cause deep skin lesions leading to necrosis, which only healed after 6-8 weeks. ${ }^{23}$ They came to the conclusion that the capacity of Freskan powder F 1001 to detoxify was insufficient and that Losantin led to better results. ${ }^{24}$ Although the healing process with these powders had been rather ineffectual, both Lendle and Wirth recommended the extension of the experiments with Freskan powder to "patients with more expanded and less penetrative LOST injuries as preferable." 25

It has been debated in historiography whether Lendle and Wirth conducted their experiments in direct cooperation with the SS physicians who had been in charge of the mustard gas experiments in Sachsenhausen. Christoph Kopke and Gebhard Schultz interpreted the relations of the army chemical warfare experts with the SS physicians as cooperation. Refuting this claim, historian Alexander Neumann emphasized that there was no hint or even a covert allusion to the Sachsenhausen experiments in the report by Lendle and Wirth (Neumann 2005, 291). However, this is not the case since Lendle and Wirth reported in two experiments about "a round blister frequently emerging around an anemic corona." They tried to "expose the base of the lesion by brushing it with a sterile steel brush, as had been done with the cases treated at Sachsenhausen." ${ }^{26}$ The explicit reference to "cases treated at Sachsenhausen" clearly indicates that Lendle and Wirth had knowledge about the medical treatment of the wounds of concentration camp inmates who were subjected to the mustard gas experiments at the time they conducted their own experiments on cadets from the Military Medical Academy. This contemporary source gives clear evidence that Lendle and Wirth, as army physicians, had established relations with the SS, which included an exchange of expert knowledge and experience from human experimentation with chemical agents and the therapeutic treatment of mustard gas injuries. After the defeat of Germany, when being interrogated in 1947 in a statutory declaration, Wirth denied any knowledge of experiments undertaken in German concentration camps. ${ }^{27}$ It was not before 1951 , when the public

\section{(Footnote 22 continued)}

Schultz (2001, 247-249), Klee (2001, 298-303), Woelk (2003, 271-276), Neumann (2005, 275276, 278-285), Kopke and Schulz (2006).

${ }^{23}$ Bericht über die Eignung der Freskanpuder F 1000 und F 1001 zur Entgiftung und Behandlung von Lostschäden der Haut, December 21, 1939, secret, signed Lendle and Wirth, p. 3, BA-MA Freiburg, RH 12-23/1728.

${ }^{24}$ Ibid., pp. 4-5, BA-MA Freiburg, RH 12-23/1728.

${ }^{25}$ Ibid., p. 6, BA-MA Freiburg, RH 12-23/1728.

${ }^{26}$ Bericht über die Eignung der Freskanpuder F 1000 und F 1001 zur Entgiftung und Behandlung von Lostschäden der Haut, December 21, 1939, secret, signed Lendle and Wirth, pp. 3-4, BA-MA Freiburg, RH 12-23/1728.

${ }^{27}$ Interrogation of Wolfgang Wirth. Office of U.S. Chief of Council for War Crimes. Vernehmung No. 799 Dr. Wirth, February 12, 1947, p. 16, National Archives, Washington, RG 282, Microfilm M1019, roll 90; Klee (1997, 302); Kopke and Schultz (2001, 246, fn. 43). 
prosecutor conducted a preliminary investigation of Schmick, including the human experiments on camp inmates with mustard gas, that Wirth admitted he had visited the camp and seen the victims in person. According to his statement from 1951, he had received an order by Generaloberstabsarzt Anton Waldmann in October or November 1939 to observe the experiments conducted in the concentration camp of Sachsenhausen. During his visit to Sachsenhausen, Wirth met with physicians who presented to him about "6, perhaps also 10 persons who had injuries approximately the size of the palm of the hand." 28 Wirth also remembered seeing a film screening at Sachsenhausen that documented the course of the disease on photographs. From what he had observed, Wirth drew the conclusion that he "could not determine a difference between persons who had been treated with the antitoxin and those who remained untreated" (Kopke and Schultz 2001, 249).

\subsection{Natzweiler}

\subsubsection{The Sulphur Mustard Experiments of August Hirt}

From 1942 to 1944 human experiments with sulphur mustard (aka LOST, named after their inventors Wilhelm LOmmel and Wilhelm STeinhaus) were conducted at the concentration camp Natzweiler on the initiative of August Hirt, SS-Sturmbannführer and director of the Anatomical Institute at the Reichsuniversität Straßburg (Mitscherlich and Mielke 1947, 92-98; Kater 1997, 248; Ebbinghaus 2000, 42-43; Steegmann 2005, 392-395; Schmaltz 2005, 531535; Reitzenstein 2014, 131-149). In doing so, Hirt received support from the SS-Ahnenerbe. So as to gain more influence in the natural sciences, the SS-Ahnenerbe established in July 1942 the Institute for Military Scientific Research with the department "H" at the Reichsuniversität Straßburg_- "H" as in Hirt. ${ }^{29}$ Commissioned by the Wehrmacht in 1939, Hirt had already studied whether the intake or injection of vitamins or their application with an ointment offered a suitable therapy for treating severe skin lesions caused by LOST. ${ }^{30}$ Supported by the SS-Ahnenerbe's General Secretary Wolfram Sievers, he succeeded in winning Himmler's approval for the LOST experiments. ${ }^{31}$ In mid-July 1942 Himmler

\footnotetext{
${ }^{28}$ Regional court councilor Meyer (Der Untersuchungsrichter des Landgerichts Duisburg), Vernehmungsprotokoll von Wolfgang Wirth, August, 28, 1951, AMMS, JD 1/22, fol. 23-25; Kopke and Schultz (2001, 248-249), Woelk (2003, 277-278).

${ }^{29}$ Himmler to Sievers, July 9, 1942, BArch, R 26 III/729, fol. 195. For Hirt's biography, see Kasten (1991), Lachmann (1977), Wojak (1999), Lang (2004, 123 ff.), Uhlmann (2011), Uhlmann and Winkelmann (2015), Reitzenstein (2014, 105 ff.).

${ }^{30}$ Hirt, Bericht über Lost-Untersuchungen im Auftrag der Wehrmacht (copy), undated, BArch, NS 19/1582, fol. 46-49; Wolfgang Wirth, Re: Hirt: interrogation of 21.9.1945 (Major Tilley), September 22, 1945, The National Archives (Kew), FO 1041/104.

${ }^{31}$ Aktenvermerk zu den Forschungen von Hirt, June 26, 1942, BArch, NS 19/1209, pp. 5-8.
} 
decreed that Hirt was to conduct his research assignments in connection with the concentration camp Natzweiler. ${ }^{32}$ Following a visit by Hirt and Sievers to the concentration camp on August 31, $1942^{33}$ the SS-Ahnenerbe administration began preparations for animal testing with LOST at Natzweiler in late September. Stables were set up, fodder provided, and stockbreeding developed. ${ }^{34}$ The experimental toxicological und pharmacological research methodology used for chemical agents during World War I, whereby human experiments were preceded with a series of animal testing and their mutual findings correlated, was also applied at Natzweiler. In late October 1942 Sievers first ordered $20 \mathrm{~g}$ of LOST for Hirt from the Waffen-SS. ${ }^{35}$ In mid-November, Hirt's assistant Karl Wimmer established a laboratory at Natzweiler and began to select inmates as test objects for the experiments. ${ }^{36}$ The first LOST experiment conducted on November 25, 1942 on 15 inmates failed because the agent provided by the Waffen-SS proved to be ineffective. ${ }^{37}$ In early December 1942 Hirt continued the experiments with a second delivery of LOST, ${ }^{38}$ which did not, however, proceed as expected. ${ }^{39}$ The results of the animal testing were not applicable to humans: Unlike the experiments on rats, the human experiments conducted on inmates showed that the Vitamin A treatment obviously did not induce protection, but quite the opposite, that is, hypersensitivity. ${ }^{40}$ In late January 1943, Sievers and Hirt discussed at Natzweiler and Dachau the extension of the LOST experiments in both concentration camps. So as to elaborate valid regulations for the troop's treatment, a "major rat experiment" was to be conducted on 1000 animals. Subsequently, the therapeutic effect of four vitamins for the treatment of LOST injuries was to be examined on $240 \mathrm{KZ}$ inmates. ${ }^{41}$ Gerit Hendrik Nales, a former Dutch inmate who worked as an orderly at the Natzweiler sick bay from November 1942, testified during the Nuremberg Doctors' Trial that between April and May 1943 a blistering substance had been smeared on the

\footnotetext{
${ }^{32}$ Rudolf Brandt an Glücks, July, 13, 1942, BArch, NS 21/904 and Sievers, Aktenvermerk, November 3, 1942; BArch, NS 21/905.

${ }^{33}$ Aktenvermerk Sievers, September 17, 1942, BArch, R 26 III/729, fol. 133.

${ }^{34}$ SS-Obersturmbannführer Vogel to SS-Ahnenerbe, September 23, 1942 and Aktenvermerk Wolff, September 28, 1942, BArch, NS 21/904.

${ }^{35}$ Chef des Amtes Ahnenerbe to SS-Hauptsanitätslager der Waffen-SS, October 22, 1942, BArch, NS 21/905.

${ }^{36}$ Hirt to Sievers, November 13, 1942, BArch NS 21/905.

${ }^{37}$ Hirt: Versuchsbericht, November 30, 1942 and Hirt to Sievers, November 26, 1942, BArch, NS $21 / 905$.

${ }^{38}$ Handschriftlicher Vermerk, December 4, 1942 concerning Hirt's "Bericht über die mit dem übersandten L-Stoff angestellten Versuche," November 30, 1942; SS-Ahnenerbe to SS-Hauptsanitätslagers der Waffen-SS, December 1, 1942; Vermerk über ein fernmündliches Gespräch mit Stabsarzt Dr. Wimmer, December 4, 1942; Wimmer, Empfangsbestätigung über 20 g Lost, December 4, 1942; Hirt to Sievers, December 22, 1942, BArch, NS 21/905.

${ }^{39}$ Hirt to Sievers, December 31, 1942, BArch, NS 21/905.

${ }^{40}$ Hirt an Sievers, January 6, 1943, BArch, NS 21/906.

${ }^{41}$ Sievers to Hirt, Bezug: Besprechungen am 25.1.1943 in Natzweiler, undated, BArch, NS 21/906.
} 
forearms of 15 German inmates, inflicting "terrible, festering wounds" on the skin that spread to the whole body and caused some inmates to go blind. ${ }^{42}$ According to Nales, three inmates died in horrible pain within a couple of days. ${ }^{43}$ The symptoms described indicate LOST experiments. The names of the victims who died of edema of the lungs or pneumonia are known: on December 21, 1942 Karl Kirn; on December 28, 1942 Friedrich Karl Tries; and on December 31, 1942, Wilhelm Müssgen (Steegmann 2010, 425; Reitzenstein 2014, 141-142). In 1944, Hirt submitted a report summarizing the results of his LOST experiments in form of a proposal for a therapy of mustard gas wounds. His report did not mention the circumstances of the experiments conducted on concentration camp inmates or the suffering of the victims. He concluded that a mix of vitamins (A, B-complex, C) given orally, or Vitamin B-1 injected with glucose would give the best results (Fig. 3). ${ }^{44}$

\subsubsection{The Phosgene Experiments of Otto Bickenbach}

On 17 March 1943 the Institute for Military Scientific Research, mentioned above, invited selected scientists from the Reichsuniversität Strasburg's medical faculty to a conference. ${ }^{45}$ One of the speakers was the physicist Otto Bickenbach-like Hirt an avid member of the NSDAP. Since 1939 Bickenbach had been researching possible treatments for the effects of the poison gas phosgene $\left(\mathrm{COCl}_{2}\right)$, which was used in combat during World War I. He had tested on animals the possible therapeutic and prophylactic effects of hexamethylenetetramine against pulmonary edema caused by phosgene poisoning (Schmaltz 2005, 521-562; 2006a). Schering AG marketed this medicine under the brand name Urotropin to treat cystitis and meningitis (Schmaltz 2005, 524). Due to the results of the animal testing, Bickenbach considered Urotropin "a very efficient protectant against the suffocation symptoms caused by the phosgene poisons." 46 At the conference, hosted by the SS-Ahnenerbe, Bickenbach screened a film he had shot himself to document the phosgene experiments conducted on cats and apes up to $1940 .{ }^{47}$ In consequence, Sievers suggested that Bickenbach continue his experiments "in connection" with Hirt in Natzweiler. ${ }^{48}$ Bickenbach agreed to the cooperation with

\footnotetext{
${ }^{42}$ Affidavit Gerrit Hendrik Nales, NO-1063, in Dörner et al. (2000b, microfiche 3/01640f).

${ }^{43}$ Interrogation of Gerrit Hendrik Nales on June 30, 1947. Trial transcript, Dörner et al. (2000b, microfiche 2/10586 ff. and 2/10594).

${ }^{44}$ Hirt and Wimmer, Behandlungsvorschlag für Kampfstoffverletzungen mit Lost, 1944 (=NO-99), BArch, NS 19/1582, fol. 74-76.

${ }^{45}$ Sievers, Aktenvermerk zu der Konferenz vom 17.3.1943, April 5, 1943, BArch, NS 21/906.

${ }^{46}$ Französische Republik. Ständiger Militärgerichtshof des sechsten Bezirks in Strassburg. Trial proceedings, May 6, 1947, NO-3848, Dörner et al. (2000a, microfiche 3/2529).

${ }^{47}$ Aktenvermerk von Sievers zu einer Unterredung mit Bickenbach am 17.3.1943 über Kampfstoff-Forschung, April 5, 1943, BArch, NS 21/906.

${ }^{48}$ Ibid.
} 
Fig. 3 August Hirt "Reichsuniversität Straßburg" (C) Hans-Joachim Lang)

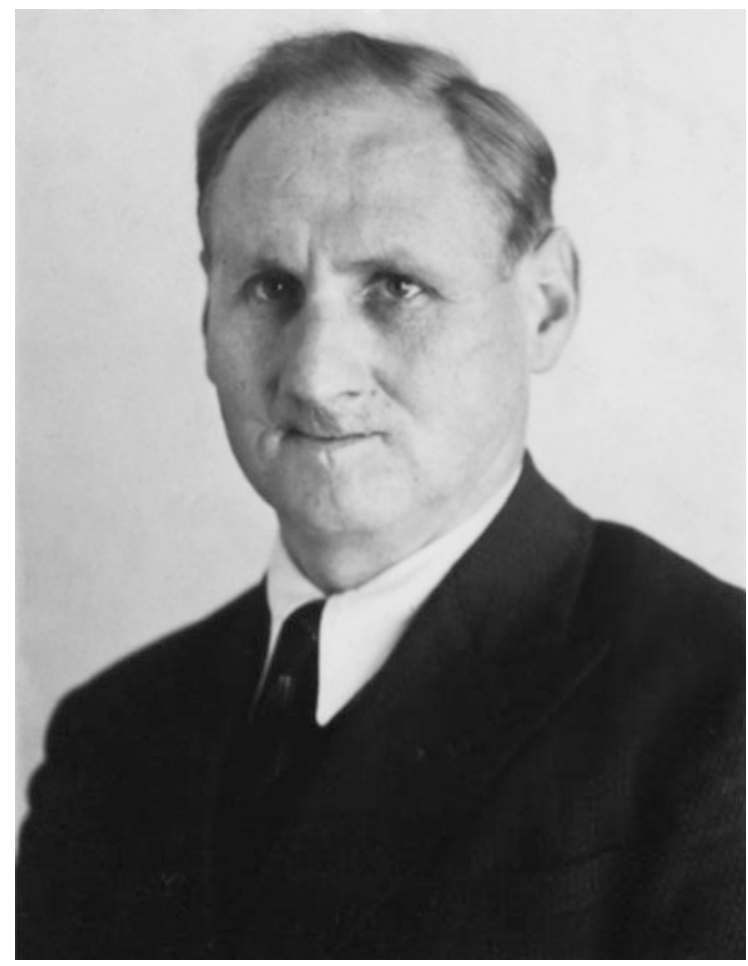

the SS because it gave him access to a large number of $\mathrm{KZ}$ inmates as test objects for his experiments. In early April 1943 Sievers asked camp commander Josef Kramer about the exact spatial volume of the gas chamber under construction there so that Bickenbach could calculate the gas concentration and thus the phosgene dose required for the human experiments. ${ }^{49}$ On April 12, 1943 Kramer reported that the gas chamber was now "completed" and had "a spatial volume of 20 cubic meters. ${ }^{.50}$ In mid-September 1942 Bickenbach agreed to cooperate with a working group at the Institute for Military Scientific Research. ${ }^{51}$ Two days after receiving the news concerning the operative gas chamber in Natzweiler, Sievers reported to Himmler in person the results of Hirt's LOST experiments so far. Bickenbach was

\footnotetext{
${ }^{49}$ Sievers to Commander of the concentration camp Natzweiler, April 5, 1943, BArch, NS 21/906.

${ }^{50}$ Kramer to SS-Ahnenerbe, Betr.: G-Zelle im KL Natzweiler, April 12, 1943, BArch, NS 21/906. Kramers specifications are not precise. In 1946, the gas chamber of the camp had been examined technically by a French commission of experts. The floor plan measured $2.40 \times 3.50 \mathrm{~m}$ with a ceiling height of $2.60 \mathrm{~m}$. The volume therefore was $21.84 \mathrm{~m}^{3}$. See Camp de Concentration du Struthof. Rapport d'expertise de MM. les professeurs et docteurs Simonin (Strasbourg), Piédelièvre (Paris) Docteur Fourcade (Strasbourg), January 15, 1946, BArch Ludwigsburg, B 162/335, fol. 66 .

${ }^{51}$ Sievers, Aktenvermerk, September 17, 1942, BArch, R 26 III/729, fol. 122.
} 
then also asked to "deliver a short report about the resistance to, or the rejection of his phosgene experiments and defense proposals by the Wehrmachtdienststellen." 52 Two weeks later, Hirt informed Bickenbach that the experiments under his responsibility could now begin. Consistent with the statement of Ferdinand Holl, a political prisoner who served as kapo (prisoner functionary) in the Natzweiler barrack reserved for the SS-Ahnenerbe, the first phosgene experiments took place in June 1943. According to his estimate, approximately 90 to 150 inmates were subjected to phosgene- 50 to 60 of whom suffocated in agony. ${ }^{53}$ Contradictory statements by Holl regarding the number of subjects involved and the number of victims who died, as well as the question of whether this early series had actually taken place, are still being discussed among historians today. ${ }^{54}$

\subsubsection{New Series of Phosgene Experiments in June and August 1944}

In 1944 the Natzweiler gas chamber was used again for several test series with phosgene. ${ }^{55}$ Helmut Rühl, Bickenbach's assistant, was responsible for the measurement of phosgene concentration in correlation to the humidity of the gas chamber. ${ }^{56}$ Rühl began to work on the construction apparatus for the measurements in January 1944 but had difficulties with the calibration of the instruments. ${ }^{57}$ The measuring method used by Rühl had been developed by Wolfgang Wirth, head of the Institute for Pharmacology and Military Toxicology of the Military Medical Academy in Berlin (Wirth 1936). Wirth visited Rühl in Strasburg and gave him advice on the final adjustment of the instruments before the last series of phosgene experiments began at Natzweiler. ${ }^{58}$ Although we do not know how much Wirth learned about the experiments conducted in the concentration camp at Natzweiler, his technical support may be seen as further

\footnotetext{
${ }^{52}$ Sievers to Hirt, April 14, 1943, BArch, NS 21/906.

${ }^{53}$ The number of test victims can no longer be clearly established. In the Nuremburg Doctor's Trial, Ferdinand Holl first gave the number as 150 victims. During cross-examination, he stated that he had witnessed about four series of experiments with LOST, each involving 30 inmates (i.e., a total of 120 inmates). According to Holl, each test series led to 7-8 casualties. Regarding the phosgene experiments, he confirmed three series, each with 30 inmates (i.e. altogether 90 victims). Cf. interrogation of Ferdinand Holl on January 6, 1947, Wortprotokoll, in Dörner et al. (2000a, microfiche 2/01092-01096).

${ }^{54}$ The testimonies of Holl have been reviewed and analyzed, Reitzenstein $(2014,134,141-142$, 168-169, 358 fn. 1007). See also Schmaltz (2005, 535 and 561), Steegmann (2005, 394-395).

${ }^{55}$ The implementation of the experimental series was delayed due to a conflict between Hirt and Bickenbach, see Schmaltz (2005, 538-543).

${ }^{56}$ Dr. Helmut Rühl an Karl Brandt, 2. Bericht: Untersuchungen über den Konzentrationsabfall des Phosgens in der Verwendeten Kammer und seine Hydrolyse unter Einfluss der Luftfeuchtigkeit, undated, NO-1852, Dörner et al. (2000a microfiche 3/02775-02777).

${ }^{57}$ Bericht von Dr. Helmut Rühl über seine Tätigkeit an dem Forschungsinstitut der Medizinischen Fakultät Straßburg, [1950], p. 2, The National Archives (Kew), FO 1060/570.

${ }^{58}$ Helmut Rühl to Karl Brandt, 2. Bericht: Untersuchungen über den Konzentrationsabfall des Phosgens in der Verwendeten Kammer und seine Hydrolyse unter Einfluss der Luftfeuchtigkeit, undated, NO-1852, Dörner et al. (2000a, microfiche 3/02775).
} 
evidence of scientific networks linking the human experiments of the Wehrmacht to criminal human experiments. ${ }^{59}$ On June 14, 1944 Bickenbach's assistants Helmut Rühl and Fritz Letz went to Natzweiler to equip the gas chamber with the measuring apparatus. Hirt and Bickenbach followed the next day and began with the phosgene experiments which ended on August 8, 1944. ${ }^{60}$ Twelve of the 40 inmates involved in the experiments were forced to take Urotropin orally; 20 inmates received injections and a "control group" of eight inmates remained "unprotected.",61 Apart from some "preventive detained" German inmates, most of the test victims had been transferred by the SS from the "Gipsy camp" Auschwitz-Birkenau to Natzweiler. The inmates had to report in groups of four to the experiments. The phosgene dose was gradually increased from experiment to experiment, while the dose of Urotropin was simultaneously reduced. Willy Herzberg, one of the survivors, told how Bickenbach himself led the inmates into the gas chamber, where he smashed vials filled with phosgene on the ground. Bickenbach then left the gas chamber and subsequently the doors were locked. After ten minutes in the gas chamber, Herzberg heard a "muffled splashing" caused by the "bursting lungs" of his fellow prisoners, who broke down with foam in their mouths, noses, and ears. ${ }^{62}$ His own breathing became distressed and he had the feeling as if "someone was sticking needles into his lungs." On his chest he sensed "a pressure, as if hundreds of kilos were put upon it," and he "already thought that he would not survive this."63 According to Bickenbach's final report, 14 inmates sustained pulmonary edema of varying degrees during the test series. In the final series, the established lethal dose of phosgene was considerably exceeded (Fig. 4).

All four inmates (Zirko Rebstock, 37; Adalbert Eckstein, 20; Andreas Hodosy, 32 and Josef Reinhardt, 38), who died at the end of the last test series, were German Sintithus indicating a systematic selection of victims based on racist criteria for the most perilous experiment. In his final report to Karl Brandt in 1944, Bickenbach explained in detail the degree to which the limit values of the lethal effects of phosgene poisoning could be reduced with Urotropin. ${ }^{64}$ The phosgene experiments at Natzweiler show that human experiments, which were unethical and without doubt a medical war crime, could still produce new scientific insights. The transgression of ethical boundaries, making the death of the test subjects an integral part of the epistemology of the

\footnotetext{
${ }^{59}$ When interrogated in 1947 , Wirth claimed that he had not heard of the phosgene experiments in Natzweiler before the Nuremberg War Crime Trials (Woelk 2003, 282). Eidesstattliche Erklärung von Wolfgang Wirth, February 2, 1947, VDB Nachtrag 1 (Hanloser), Dörner et al. (2000a, microfiche 4/4171-4173).

${ }^{60}$ Staatsanwaltschaft Bochum: Vernehmungsprotokoll von Otto Bickenbach, November 4, 1955 , BArch Ludwigsburg, B 162/4206, fol. 1093f.

${ }^{61}$ Bickenbach to Karl Brandt: 7. Bericht. Die schützende Wirkung einer Inhalation von Hexamethylentetramin-Aerosol auf die Phosgenvergiftung, undated, p. 15, NO-1852, Dörner et al. (2000a, microfiche 3/02791).

${ }^{62}$ Staatsanwaltschaft Holtfort: Zeugenvernehmung von Willy Herzberg, July, 1, 1981, BArch Ludwigsburg, B 162/19282, fol. 80.

${ }^{63}$ Ibid., 81.

${ }^{64}$ Bickenbach to Brandt, 7. Bericht, undated, NO-1852, (Dörner et al. 2000a, microfiche 3/02794).
} 
Fig. 4 Otto Bickenbach in French imprisonment (Bayle $1950,925)$

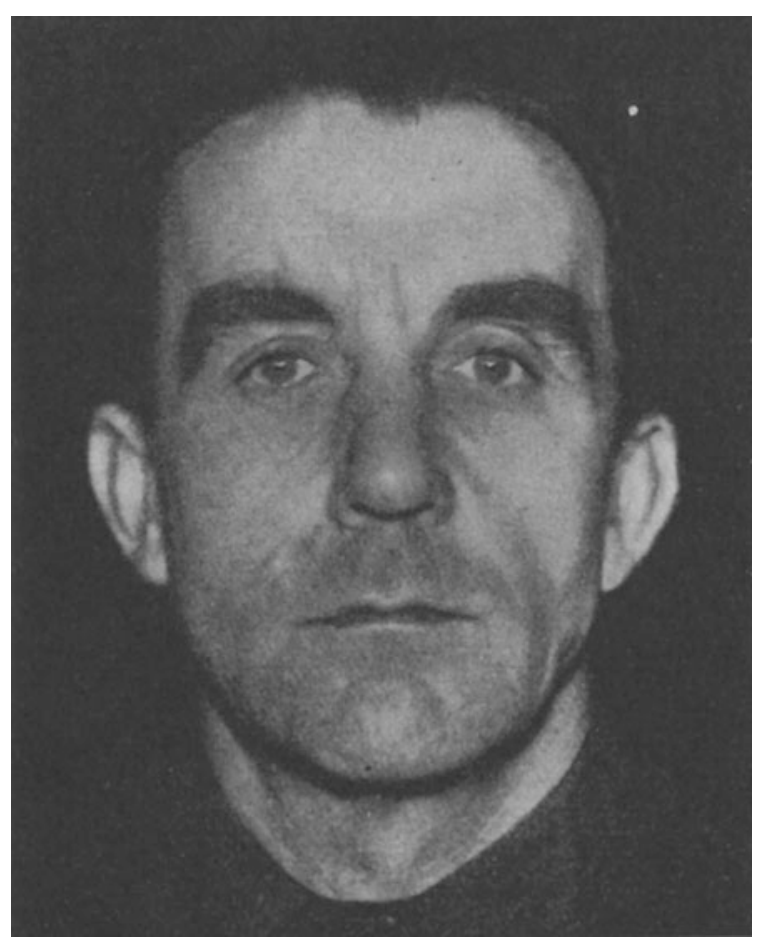

experiments in the context of brutal and dehumanized medicinal practice, delivered empirical data that could not have been obtained under any other circumstances.

\subsection{Neuengamme}

The last series of experiments with chemical warfare agents in a concentration camp took place between December 1944 and March 1945 at Neuengamme (Groehler 1978, 277-279; 1989, 240-242; Klee 1997, 177-179; Kalthoff and Werner 1999, 193-196). They were initiated by the head of the Reichsanstalt für Wasser- und Luftgüte, Professor Karl Ludwig Werner Haase (Fig. 5). ${ }^{65}$

\footnotetext{
${ }^{65}$ Karl Ludwig Werner Haase (1903-1980) studied chemistry in Berlin, where he also worked on his dissertation at the Kaiser Wilhelm Institute für physical Chemistry and Electro Chemistry. He completed this in 1924 at the Institut for Plant Nutrition (Institut für Pflanzenernährung) in Hohenheim. In 1925 he received his doctorate in Berlin and started to work for the Preußische Landesanstalt für Wasser-, Boden- und Lufthygiene (in 1942 renamed Reichsanstalt für Wasserund Luftgüte). Haase joined the NSDAP in April 1940. During World War II he was a member of a commission of the Speer Ministry (Reichsministerium für Rüstung- und Kriegsproduktion) that dealt with development of mobile drinking water devices. See Affidavit Werner Haase, January 27,
} 


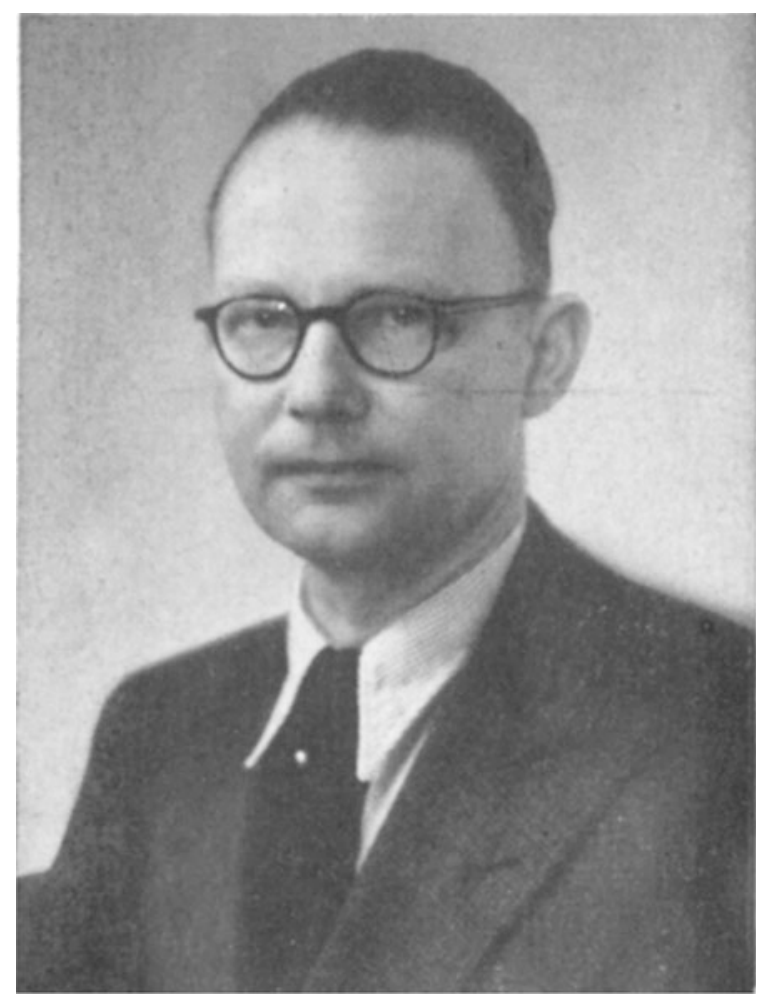

Fig. 5 Ludwig Werner Haase (Werkstoffe und Korrosion, 6. Jg., 1955, 2. Innenseite: "Die Vortragenden der Korrosionstagung/DECHEMA-Jahrestagung-11. und 12. November 1954 in Frankfurt/Main")

Following the destruction of the large water dam "Möhne Reservoir" by a Royal Air Force air raid in May 1943, Haase was assigned as a consultant for its restoration. Once he had alerted the president of the Reichsanstalt to the possible risk of the Allied Forces contaminating the water with bacteria, glass dust, viruses, or chemical agents, Haase was authorized to explore new decontamination methods for chemical agents in laboratory research. ${ }^{66}$ In spring 1944 Haase advanced a new method for the decontamination of water that had been poisoned with the blister agent Lewisite $\left[\mathrm{C}_{2} \mathrm{H}_{2} \mathrm{AsCl}_{3}\right.$; dichloro(2-chlorovinyl)arsine]. This involved the

\section{(Footnote 65 continued)}

1947, VDB 1, Dörner et al. (2000a, microfiche 3/4996); BArch, NSDAP Ortsgruppenkartei, Haase, Ludwig Werner, born May 2, 1903. See also the entries on Haase in Kürschners Gelehrten-Lexikon, Oestreich (1954, 761), Schuder (1961, 633-634; 1970, 945).

${ }^{66}$ Aussage von Ludwig Werner Haase, November 21, 1963, BArch Ludwigsburg, B 162/1001, fol. $365-366$. 
application of hypochlorous acid. ${ }^{67}$ The organic arsenic agent Lewisite, produced as a chemical weapon during World War I, causes severe blistering and burns, resulting when ingested in great pain, nausea, vomiting, and tissue damage (Pechura and Rall 1993; Bey and Walter 2003). The Wehrmacht immediately tested Haase's method at Raubkammer/Munsterlager. ${ }^{68}$ Within the Military Medical Academy, Haase's method was controversial because the first results of the decontamination experiments were ambiguous. ${ }^{69}$ In summer 1944 the Institute for Pharmacology and Military Toxicology headed by Wolfgang Wirth investigated the toxicity of Lewisite decomposition products. ${ }^{70}$ By the end of August 1944, the apparatus for the decontamination process was available. ${ }^{71}$ In late September 1943 the president of the Reichsanstalt für Wasser- und Luftgüte sent a copy of Haase's preliminary report to the head of the Ministry of Interior's health department, Fritz Cropp, who in turn forwarded it to Reich Health Leader Leonardo Conti. ${ }^{72}$ SS-Obergruppenführer Conti immediately submitted the report to Himmler asking for support to further develop the new method of decontamination since traditional procedures would fail due to the insufficient availability of active charcoal for such large amounts of water. ${ }^{73}$ Himmler authorized experiments in a concentration camp and Neuengamme was chosen as the location. ${ }^{74}$

Haase and his assistant Dr. Jaeger had been preparing the experiments since June 1944 and planned to install the decontamination apparatus by the end of July at the Neuengamme concentration camp. On August 5 and September 1, 1944 they visited

\footnotetext{
${ }^{67}$ Ibid.

${ }^{68}$ Ibid.

${ }^{69}$ While the head of the Institut für Wehrpharmazie und angewandte Chemie, Konrad Gemeinhardt, pled against follow-up studies, the head of the Institut für Pharmakologie und Wehrtoxikologie, Wolfgang Wirth, recommended further investigations. See Hemmrich (Der Sonderbeauftragte des Reichsministers für Rüstung und Kriegsproduktion für die Entseuchung und Entgiftung von Trink- und Brauchwasser: Niederschrift über die Besprechung am 28.4.1944, May 5, 1944, p. 3, BA-MA Freiburg, RH 12-23/1707.

${ }^{70} \mathrm{OKH}$ Chef H Rüst u SAN (Nr $9360144 \mathrm{~g}$ S In II G III) to Ministerialrat Georg Hemmrich, Betr.: Genußfähigkeit arsenhaltigen Trinkwassers, August, 28, 1944, BA-MA Freiburg, RH 12-23/1707 and Wirth to Zettel (Generalkommissar des Führers für das Sanitäts- und Gesundheitswesen), Betr.: Kampfstoffentgiftung von Wasser (draft), secret, August 24, 1944, ibid.

${ }^{71}$ Zettel to Wirth, August 19, 1944, BA-MA Freiburg, RH 12-23/1707 and Wirth to Zettel, August 24, 1944, ibid.

${ }^{72}$ Reichsanstalt für Wasser- und Luftgüte to Ministerialdirektor Dr. Cropp, September 27, 1943, BArch, NS 19/3819, fol. 2 and Rudolf Brandt (Personal Staff RFSS) to Reichsarzt-SS und Polizei Dr. Grawitz, October 8, 1943, ibid., fol. 3.

${ }^{73}$ Conti to Himmler, October 1, 1943, BArch, NS 19/3819, fol. 1. In 1944, the shortage of active charcoal was so severe that the army could not meet its demands for gas mask filters, see Schreiben der Heeres-Rohstoffabteilung unter Az. 66 b 91.30 H Ro Va zu Nr. 99/44 v. 22.8.44 to San In./Org II, Betr.: Trinkwasser und Entgiftung (Geheime Kommandosache), BA-MA Freiburg, RH 12-23/1707.

${ }^{74}$ Rudolf Brandt to Reichsarzt-SS und Polizei Dr. Grawitz, October 8, 1943, BArch, NS 19/3819, p. 3; Rudolf Brandt to Conti, October 3, 1943, ibid., p. 4 and Grawitz to Rudolf Brandt, March 30, 1944, ibid., p. 6.
} 
Neuengamme. ${ }^{75}$ Probably on one of these days, hypochlorous acid was added to the drinking-water supply at Neuengamme to perform a large-scale test on approximately 10,000 inmates to see if the water with the added decontamination compound would lead to health problems. ${ }^{76}$ According to Haase and Regierungsbauinspektor Kumpfert, no observed health problems were reported after consumption of the water with the decontamination compound. ${ }^{77}$ On October 10, 1944 Haase continued testing with Wolfgang Wirth from the Military Medical Academy at the army's proofing ground at Raubkammer. ${ }^{78}$

In November the Personal Staff of Reichsführer SS asked for the promised results. $^{79}$ By the end of November, Haase announced that he and his research assistant Dr. Jaeger would prepare and conduct the experiments at Neuengamme. Haase attributed the delay of the experiments to the difficulties presented by the required physiological pre-examinations conducted by the director of the Pharmacological Institute Felix Haffner at the University of Tübingen, as well as the results of other institutes at Dresden, Hamburg, Raubkammer, and Wuppertal regarding a possible effect of poor water quality on the results. ${ }^{80}$ Haffner's research project was authorized by the Heereswaffenamt and furthered by the Reich Research Council (Fig. 6). ${ }^{81}$

By the end of November Helmut Poppendick, Chief of Personal Staff of the Reichsführer SS and Police, acting as designated principal investigator at Neuengamme, characterized the human experiments at Neuengamme as a "control experiment on a large scale for a final assurance" of the decontamination method,

\footnotetext{
${ }^{75}$ See the Tagesjournal der Reichsanstalt für Wasser- und Luftgüte, daily journal entries dating June 7, July 28.7. August 5, and September 1, 1944, Archiv des Umweltbundesamtes, Tagesjournale. I am grateful to Dr. Karsten Linne who informed me about these documents.

${ }^{76}$ Grawitz telexed to Rudolf Brandt on September 8, 1944 that the hypochlorous acid had proven harmless ("WIRKSAEURE IN DEN NOTWENDIGEN KONZENTRATIONEN KEINE GESUNDHEITSCHAEDIGUNG VERUSACHT") and that new experiments with chemical agents would start now (Telex Grawitz to Rudolf Brandt, September 8, 1944, BArch, NS 19/3819, fol. 8). For the number of concentration camp inmates exposed to the detoxification acid, see Friedrich Konrich (Präsident der Reichsanstalt für Wasser- und Luftgüte). Berichterstatter Haase und Regierungsbauinspektor Kumpfert: 13. Bericht über die Wirkung hoher W-Säurekonzentrationen im Wasser auf Menschen und Tiere, October 26, 1944, Staatsarchiv Nürnberg, KV-Anklage, Dokumente, NO-153.

${ }^{77} 13$. Bericht über die Wirkung hoher W-Säurekonzentrationen im Wasser auf Menschen und Tiere, October 26, 1944, Staatsarchiv Nürnberg, KV-Anklage, Dokumente, NO-153.

${ }^{78}$ Wirth (Wi G III) to Org II, Betr.: Entgiftung von Trinkwasser, (draft), October 31, 1944, BA-MA Freiburg, RH 12-23/1707 and Wirth to Karl Brandt, Betr.: W-Säureverfahren von Prof. Haase, December 13, 1944, BA-MA Freiburg, RH 12-23/1740.

${ }^{79}$ Telex from Rudolf Brandt to Poppendick, November 3, 1944, BArch, NS 19/3819, fol. 9.

${ }^{80}$ Haase spoke of the "Außenstellen in Dresden, Hamburg, Raubkammer und Wuppertal." Except for the Heeresversuchsanstalt at Raubkammer, it is not clear which laboratories he meant, see Haase: Aktenvermerk, November 22, 1944, BArch, NS 19/3819, fol. 11.

${ }^{81}$ For Haffner's research project, see Felix Haffner, Wasserentgiftungsmethoden (Kampfstoffe). Pharmakologisches Institut Universität Tübingen. OH-09/0012-DE-009/752/43 Gkdos. Oberregierungsrat Dr. Wagner. approved September 1943, BArch, R 26 III/12.
} 
Fig. 6 Helmut Poppendick, November 5, 1947 at Nuermberg (Courtesy of the United States Holocaust Memorial Museum, Photograph \#07322)

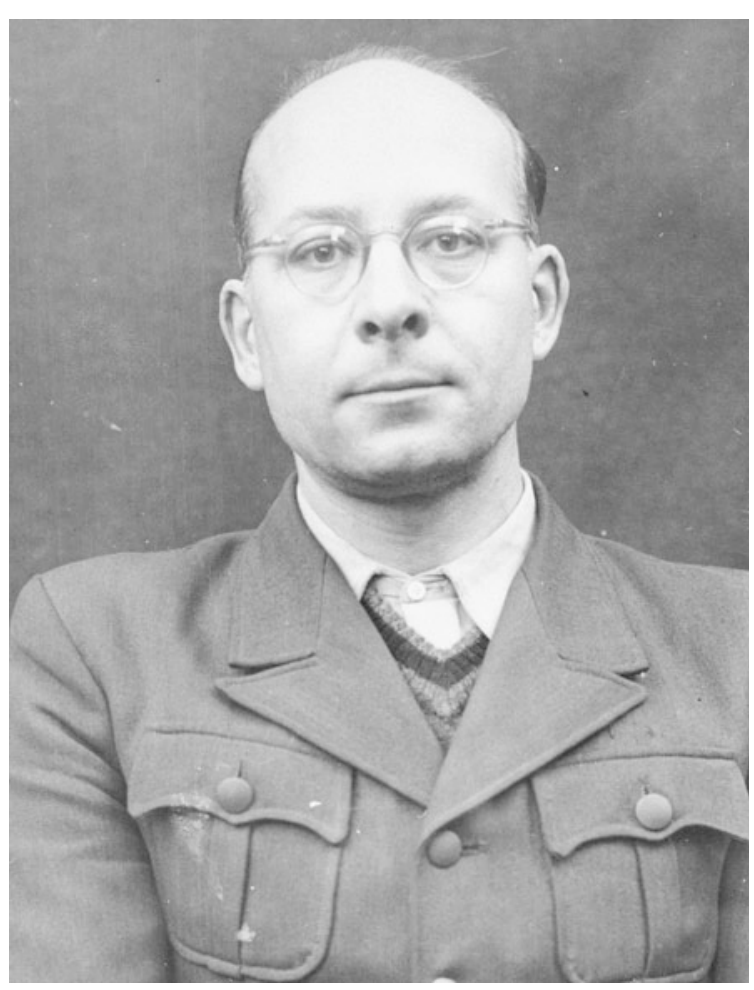

since Haase and his collaborators had allegedly already continuously drunk the decontaminated water without suffering any health damages. By that time, 1200 units of the decontamination apparatus were already in production. ${ }^{82}$ In early December 1944 Karl Brandt asked Wirth for a statement on the Haase method. ${ }^{83}$ Wirth was not able to provide an evaluation report since he had not received the relevant report from Haase. Complaining about an insufficient supply of research data, Wirth conducted comprehensive toxicological and pathohistological experiments to establish an empirical basis for the evaluation of Haase's methods. Wirth promised to submit a report to the Reichsführer SS by mid-December 1944 (Table 3). ${ }^{84}$

Between December 3 and 15, 1944 approximately 150 inmates of a so-called "Schonbaracke (recovery barrack) at Neuengamme were subjected to the drinking water experiments. According to Haase's report, the water had first been poisoned with Lewisite for 15 days, with doses increasing in rates of up to a maximum of

\footnotetext{
${ }^{82}$ Helmut Poppendick to Rudolf Brandt, November 23, 1944, BArch, NS 19/3819, fol. 10.

${ }^{83}$ Karl Brandt to Wirth, December 6, 1944, BA-MA Freiburg, RH 12-23/1740.

${ }^{84}$ Wirth to Karl Brandt, Betr.: W-Säureverfahren von Prof. Haase, December 13, 1944, BA-MA Freiburg, RH 12-23/1740.
} 
Table 3 Lewisite and mustard gas experiments at the concentration camp Neuengamme

\begin{tabular}{l|l|l|l}
\hline Date & Agent & Number of test persons & Involved \\
\hline $\begin{array}{l}\text { 5 Aug. and } \\
1 \text { Sept.1944 }\end{array}$ & $\begin{array}{l}\text { Hypochlorous acid (compound } \\
\text { for decontamination) }\end{array}$ & $\begin{array}{l}\text { Approx. 10,000 } \\
\text { concentration camp } \\
\text { inmates }\end{array}$ & $\begin{array}{l}\text { Haase } \\
\text { Jaeger }\end{array}$ \\
\hline 3 Dec.- \\
12 Dec.1944 & Lewisite & Approx. 150 & \\
\cline { 2 - 2 } & Dora (Lewisite dry) & & Poppendick \\
\cline { 2 - 3 } $\begin{array}{l}\text { Planned in } \\
\text { Feb.1945 }\end{array}$ & N CW agents & 16 planned & \\
\cline { 2 - 4 } & Nitrogen mustard & & \\
\hline
\end{tabular}

"approximately 100-fold" the amount the Military Medical Academy considered noxious. ${ }^{85}$ Purportedly, the SS camp physicians did not observe any health damage in the camp prisoners. ${ }^{86}$ The experiments included two different agents: Lewisite and Dora (a dry form of Lewisite) were used. SS-Oberführer Helmut Poppendick concluded from Haase's report that further experiments in January were necessary to establish possible damage caused by long-term consumption of the water since the amount of arsenic ingested was still considered "significant." Himmler did not consider further experiments necessary since the dosage tested had been high enough ${ }^{88}$ Haase and SS-Sturmbannführer Hermann Friese, who acted as an expert consultant for the SS in issues of chemical warfare, favored further experiments after hearing about Himmler's skeptical appraisal. He argued that additional experiments with nitrogen mustard gas were necessary because this agent had a different chemical composition and reaction than Lewsiste, the arsenic compound tested so far. The experiments with nitrogen mustard were conducted in January $1945 .{ }^{89}$ In February 1945 Poppendick reported that the nitrogen mustard experiments had been completed and achieved the "same favorable result." "90

As stated in a final report by the Reichsanstalt für Wasser- und Lufthygiene in March 1945, this series of tests with nitrogen mustard gas had actually been initiated by Wolfgang Wirth during a meeting with Karl Brandt as early as December 4,1944 , one day after the experiments on concentration camp inmates had begun. ${ }^{91}$

\footnotetext{
${ }^{85}$ The report written by Haase is quoted in the letter from SS-Oberführer Poppendick (Reichsführer-SS - Reichsarzt-SS und Polizei) to Rudolf Brandt, December 20, 1944, BArch, NS 19/3819, fol. 12.

${ }^{86}$ Ibid.

${ }^{87}$ SS-Oberführer Poppendick to Rudolf Brandt, December 20, 1944, BArch, NS 19/3819, fol. 12.

${ }^{88}$ Rudolf Brandt to Poppendick, December 31, 1944, BArch, NS 19/3819, fol. 13.

${ }^{89}$ For the academic career of Friese, see also Albrecht et al. $(1991,74)$.

${ }^{90}$ Poppendick to Rudolf Brandt, February 8, 1945, BArch, NS 19/3819, 15.

${ }^{91}$ Konrich (Präsident der Reichsanstalt für Wasser- und Luftgüte). Berichterstatter: Dr. Jaegers und Regierungs-Bauinspektor Kumpfert. Bericht Nr. 25 über die in Hamburg-Neuengamme durchgeführten Versuche vom 30.3.1945, in Staatsarchiv Nürnberg, KV-Anklage, Dokumente, NO-154.
} 
In an affidavit for the defense in the Nuremberg Doctors' Trial, Wirth confirmed that he probably attended a meeting in Brandt's office on December 12, 1944 when two devices for the decontamination of water poisoned with chemical agents were discussed. Wirth denied having given advice to extend the experiments with nitrogen mustard. ${ }^{92}$ Though the report by Konrich gives no evidence that Wirth personally visited Neuengamme, or that he participated directly in the experiments, his advice, however, led to its implementation in January 1945 when inmates were forced to drink decontaminated water that had been previously poisoned with nitrogen mustard gas. This shows that the chemical warfare researchers from army agencies were not only aware of the unethical experiments undertaken in German concentration camps, but were actually involved as expert consultants in the specific division of labor for the SS physicians in the camps.

After the nitrogen mustard experiments were completed in early February 1945, the scientists proposed another series of experiments with a far more radical approach to forced human participation. The experimental design now not only included intentional health damage and disabilities, but even the death of camp inmates. Poppendick urged that the ingestion of chemical agents be examined in more detail since all available data on harmful doses were "nothing but a pure guess." 93 According to Poppendick's letter, Haase wanted to force eight concentration camp inmates to ingest eight important chemical agents in harmful doses, and another eight inmates to ingest a lower dose that he considered harmless, in order to determine the threshold: "Since damage or cases of death do not have to be taken into account for the first eight test persons, prisoners facing death sentences should be used." 94

On February 16, 1945 Himmler withdrew his approval "in consideration of the current situation." 95 This was, as far as we know, the first time ever that Himmler refused to allow human experiments to be conducted in a concentration camp. Even with the advance of the Allied Forces and Germany's final defeat unavoidable, the scientists still tried to make use of the last opportunity to exploit the lives of the concentration camp inmates at their disposal and ruthlessly subjected them to lethal

\footnotetext{
${ }^{92}$ Eidesstattliche Erklärung von Wolfgang Wirth, Feb. 2, 1947, VDB Nachtrag 1 (Hanloser), Dörner et al. (2000a, microfiche 4/4171-4173). Woelk (2003, 282) does not discuss the reliability of Wirth's affidavit. As Kopke and Schultz have shown, Wirth committed perjure when he denied under oath that he had absolutely no knowledge of human experiments in German concentration camps, see Kopke and Schultz (2001, 247-249), Schmidt (2007, 295). Karl Brandt and Siegfried Hanloser denied any specific knowledge of the involvement of Wirth in the water decontamination experiments at Neuengamme: Kreuzverhör von Karl Brandt (34. Verhandlungstag), February 2, 1947, Microfiche-Edition Ärzteprozess, Dörner et al. (2000a, microfiche 2/02654-2655); Kreuzverhör Siegfried Hanloser (39. Verhandlungstag), February 18, 1947, ibid., microfiche 2/03057-3059.

${ }^{93}$ Poppendick to Rudolf Brandt, February 8, 1945, BArch, NS 19/3819, fol. 15. ${ }^{94}$ Ibid.

${ }^{95}$ Handwritten note by Rudolf Brandt from February 16, 1945, see Poppendick to Rudolf Brandt, February 8, 1945, BArch, NS 19/3819, fol. 15.
} 
human experiments. In March 1945 Dr. Jaeger visited Neuengamme again. ${ }^{96}$ Whether his intention was to retrieve the decontamination apparatus or to conduct the final experiments remains unclear.

\section{Conclusion}

Concerning the issue of the informed consent of subjects on whom experiments with chemical agents were performed, the crucial question of voluntary participation and informed consent mark an important difference between those experiments conducted under the auspices of military institutions, or those that took place in the concentration camps. While the former provided some room for manoeuvre, this was not the case in the concentration camps. For those experiments, there was no informed consent and no attempts were made to avoid the unnecessary suffering. The experiment designs of August Hirt, Otto Bickenbach, and Ludwig Haase took the death of involuntary test persons into account. In the case of Haase, it was only the impending military defeat of Nazi Germany that fortunately inhibited the implementation of the last deadly series of experiments.

Cooperation, competition, and division of labor went hand in hand. As the examples presented here have shown, competition and rivalry between chemical warfare experts from the military and the SS led to a specific division of labor in human experimentation with chemical agents. Plans to conduct the human experiments in concentration camps were not always initiated by the SS, August Hirt, or Helmut Poppendick. As the cases involving airforce officers Bickenbach and Haase from the Reichsanstalt für Wasser- und Luftgüte show, scientists from other groups and institutions, in addition to the SS, were also driving forces in conducting criminal experiments on decontamination methods for drinking water poisoned with chemical agents. Sources indicate that it is also likely that Wolfgang Wirth, head of the Institute for Pharmacology and Military Toxicology of the Military Medical Academy, proposed to expand those experiments on concentration camp inmates at Neuengamme to investigate nitrogen mustard.

For a better understanding of human experimentation during the Nazi regime, it is crucial to analyze historically the epistemology of human experimentation and to take seriously the research motivation and aims of the scientists involved. Knowledge production and dissemination of human experimentation with chemical agents was not restricted to SS doctors, but included a much broader group of scientists in the army and airforce, at universities, in research organizations such as the renowned Deutsche Forschungsgemeinschaft and the Reich Research Council, or at the Reichsanstalt für Wasser und Luftgüte.

\footnotetext{
${ }^{96}$ Eintrag Nr. 35/2 zu den Reisekosten Jaegers nach Hamburg-Neuengamme vom 6.3.1945 im Tagesjournal 1945 der Reichsanstalt für Wasser- und Luftgüte, Archiv des Umweltbundesamtes, Tagesjournale. I would like to thank Dr. Karsten Linne, who found this document, for generously supplying a copy.
} 


\section{References}

Albrecht, Helmuth, Bettina Gundler, and Technische Universität Braunschweig. 1991. Catalogus professorum der Technischen Universität Carolo-Wilhelmina zu Braunschweig. Beiträge zur Geschichte der Carolo-Wilhelmina 9. Braunschweig.

Baader, Gerhard. 2002. Lost-Levisit-Kampfstoffversuche in der deutschen Militärmedizin, 19391945. Virus. Beiträge zur Sozialgeschichte der Medizin 3: 12-28.

Bayle, François. 1950. Croix gammée contre caducée. Les expériences humaines en Allemagne pendant la deuxième guerre mondiale. Neustadt: Centre de L'Imprimerie Nationale.

Bey, Tareg, and Frank G. Walter. 2003. Senfgas, Stickstofflost, Lewisit und Phosgenoxim. Hautschädigende Militärkampfstoffe und deren Bedeutung für Rettungsdienste. Notfall \& Rettungsmedizin 6(5): 327-336.

Brauch, Hans Günter, and Rolf Dieter Müller. 1985. Chemische Kriegführung-Chemische Abrüstung. Dokumente und Kommentare. Berlin: Arno Spitz Verlag.

Czernik, Hendryk. 1974. Filie obozu koncentracyjnego Gross-Rosen w Brzegu Dolnym (Dyhernfurth I i II). Studia nad faszyzmem i zbrodniami hitlerowskimi, 191-248.

Dörner, Klaus, Angelika Ebbinghaus, Karsten Linne, Karl Heinz Roth, and Paul Weindling. 2000a. Der Nürnberger Ärzteprozeß 1946/47. Wortprotokolle, Anklage- und Verteidigungsmaterial, Quellen zum Umfeld. München: K.G. Saur.

Dörner, Klaus, Angelika Ebbinghaus, Karsten Linne, Karl Heinz Roth, and Paul Weindling. 2000b. Der Nürnberger Ärzteprozeß 1946/47. Wortprotokolle, Anklage- und Verteidigungsmaterial, Quellen zum Umfeld. Erschließungsband zur Mikrofiche-Edition: Bearbeitet von Karsten Linne. München: K.G. Saur.

Ebbinghaus, Angelika. 1998. Der Prozeß gegen Tesch \& Stabenow. Von der Schädlingsbekämpfung zum Holocaust. 1999. Zeitschrift für Sozialgeschichte des 20. und 21. Jahrhunderts 13(2): 16-71.

Ebbinghaus, Angelika. 1999. Chemische Kampfstoffe in der deutschen Rüstungs- und Kriegswirtschaft. In Krieg und Wirtschaft. Studien zur deutschen Wirtschaftsgeschichte 1939-1945, ed. Dietrich Eichholtz, 171-194. Nationalsozialistische Besatzungpolitik in Europa 1939-1945. Berlin: Metropol-Verlag.

Ebbinghaus, Angelika. 2000. Einleitung. In Der Nürnberger Ärzteprozeß 1946/47. Wortprotokolle, Anklage- und Verteidigungsmaterial, Quellen zum Umfeld. Erschließungsband zur Mikrofiche-Edition, eds. Klaus Dörner, Angelika Ebbinghaus, Karsten Linne, Karl Heinz Roth, and Paul Weindling. Bearbeitet von Karsten Linne, 11-69. München: K.G. Saur.

Eberle, Henrik. 2015. Ein wertvolles Instrument. Die Universität Greifswald im Nationalsozialismus. Köln: Böhlau.

Gellermann, Günther W. 1986. Der Krieg, der nicht stattfand. Möglichkeiten, Überlegungen und Entscheidungen der deutschen Obersten Führung zur Verwendung chemischer Kampfstoffe im zweiten Weltkrieg. Koblenz: Bernhard \& Graefe Verlag.

Grodin, Michael A. 1992. Historical Origins of the Nuermberg Code. In The Nazi Doctors and the Nuremberg Code. Human Rights in Human Experimentation, eds. George J. Annas, and Michael A. Grodin, 121-144. New York: Oxford University Press.

Groehler, Olaf. 1978. Der lautlose Tod. Berlin (DDR): Verlag der Nation.

Groehler, Olaf. 1989. Der lautlose Tod. Einsatz und Entwicklung deutscher Giftgase von 1914 bis 1945. Reinbek: Rowohlt.

Groehler, Olaf. 1992. Selbstmörderische Allianz. Deutsch-russische Militärbeziehungen 19201941. Berlin: Vision Verlag. 
Hahn, Judith. 2008. Grawitz, Genzken, Gebhardt. Drei Karrieren im Sanitätsdienst der SS. Münster: Klemm \& Oelschläger.

Hayes, Peter Francis. 2004. From cooperation to complicity. Degussa in the Third Reich. Cambridge: Cambridge University Press.

Joly, Hervé. 2000. L'implication de l'industrie chimique allemande dans le Shoah: Le cas de Zyklon B. Revue d'histoire moderne et contemporaire 47 (April-Juni): 368-400.

Jones, Irving H. 1945. I.G. Farbenindustrie A.G. Frankfurt/Main. CIOS File No. XXX-19 (Item 30), ed. SHAEF Combined Intelligence Objectives Sub-Committee - G-2 Division.

Kalthoff, Jürgen, and Martin Werner. 1999. Die Händler des Zyklon B. Hamburg: VSA Verlag.

Kasten, Frederick H. 1991. Unethical Nazi Medicine in Annexed Alsace-Lorraine: The Strange Case of Nazi Anatomist Professor Dr. August Hirt. In Historians and archivists. Essays in modern German history and archival policy, ed. G.O. Kent, 173-208. Fairfax, Va.: George Mason University Press.

Kästner, Ingrid, and Susanne Hahn. 1994. Der Toxikologe Otto Muntsch (1890-1945) und die deutsche Kampfstofforschung. 1999. Zeitschrift für Sozialgeschichte des 20. und 21. Jahrhunderts 9(3): 42-50.

Kater, Michael H. 1997. Das “Ahnenerbe” der SS 1935-1945. Ein Beitrag zur Kulturpolitik des Dritten Reiches, 2nd ed. Studien zur Zeitgeschichte 6. München: R. Oldenbourg.

Klee, Ernst. 1997. Auschwitz, die NS-Medizin und ihre Opfer. Frankfurt am Main: S. Fischer Verlag.

Klee, Ernst. 2001. Deutsche Medizin im Dritten Reich. Karrieren vor und nach 1945. Frankfurt am Main: Fischer Verlag.

Kopke, Christoph, and Gebhard Schultz. 2001. Menschenversuche mit chemischen Kampfstoffen bei der Wehrmacht und SS. Ein Forschungsbericht. In Medizin und Verbrechen. Festschrift für Walter Wuttke, ed. Christoph Kopke, 239-257. Ulm: Klemm \& Oelschläger.

Kopke, Christoph, and Gerhard Schulz. 2006. Die Menschenversuche mit dem Kampfstoff Lost im KZ Sachsenhausen (1939) und die Debatte über die Rolle des Wehrmachtstoxikologen Wolfgang Wirth. In Medizin im Zweiten Weltkrieg, ed. Wolfgang U. Eckart, and Alexander Neumann, 113-129. Paderborn: Schönigh.

Krause, Joachim, and Charles K. Mallroy. 1993. Chemische Waffen in der Militärdoktrin der Sowjetunion. Historische Erfahrungen und militärische Lehren 1919-1991. Baden-Baden: Nomos-Verlag.

Lachmann, Ernest. 1977. Anatomist of infamy: August Hirt. Bulletin of the History of Medicine 51: 594-602.

Lang, Hans-Joachim. 2004. Die Namen der Nummern. Wie es gelang, die 86 Opfer eines NS-Verbrechens zu identifizieren. Hamburg: Hoffmann und Campe.

Ley, Astrid, and Günter Morsch. 2007. Medizin und Verbrechen. Das Krankenrevier des KZ Sachsenhausen 1936-1945. Schriftenreihe der Stiftung Brandenburgische Gedenkstätten 21. Berlin: Metropol-Verlag.

Martinetz, Dieter. 1996. Vom Giftpfeil zum Chemiewaffenverbot. Zur Geschichte der chemischen Kampfmittel. Frankfurt am Main: Verlag Harri Deutsch.

Mills, A.K. 1945. Investigations of Chemical Warfare Installations in the Munsterlager area, including Raubkammer. CIOS File No. XXXI-86, ed. SHAEF Combined Intelligence Objectives Sub-Committee-G-2 Division, London.

Mitscherlich, Alexander, and Fred Mielke. 1947. Das Diktat der Menschenverachtung. Eine Dokumentation. Heidelberg: Verlag Lambert Schneider.

Morsch, Günter, and Bertrand Perz, eds. 2011. Neue Studien zu nationalsozialistischen Massentötungen durch Giftgas: Historische Bedeutung, technische Entwicklung, revisionistische Leugnung. Schriftenreihe der Siftung Brandenburgische Gedenkstätten. Berlin: Metropol-Verlag. 
Müller, Rolf Dieter. 1985. World power status through the use of poison gas? German preparations for chemical warfare, 1919-1945. In The German military in the age of total war, ed. Wilhelm Deist, 171-209. Warwickshire: Berg Publishers.

Neumann, Alexander. 2005. "Arzttum ist immer Kämpfertum". Die Heeressanitätsinspektion und das Amt "Chef des Wehrmachtssanitätswesens" im Zweiten Weltkrieg. Düsseldorf: Droste.

Oehler-Klein, Sigrid, and Alexander Neumann. 2004. Die Militarisierung der Medizin an der Universität Gießen und ihre Beziehungen zu den Sanitätsinspektionen von Heer und Luftwaffe im Zweiten Weltkrieg. Mitteilungen des Oberhessischen Geschichtsvereins Gießen 89: 95188.

Oestreich, Gerhard. 1954. Kürschners deutscher Gelehrten-Kalender 1954, 8th ed. Berlin: de Gruyter.

Pechura, Constance M., and David P. Rall. 1993. Veterans at risk: The health effects of mustard gas and lewisite. Washington, D.C.: National Adademy Press.

Reitzenstein, Julien. 2014. Himmlers Forscher: Wehrwissenschaft und Medizinverbrechen im "Ahnenerbe" der SS. Paderborn: Schöningh.

Roelcke, Volker. 2017. The use and abuse of medical research ethics: The German Richtlinien/guidelines for human subject research as an instrument for the protection of research subjects - and of medical science, ca. 1931-1961/64. In From clinic to concentration camp: Reassessing Nazi medical and racial research, 1933-1945, ed. Paul Weindling, 33-56. Milton Park: Routledge.

Rundschreiben des Reichsministers des Inneren vom 28.2.1931: Richtlinien für die neuartige Heilbehandlung und für die Vornahme wissenschaftlicher Versuche am Menschen. 1931. Reichsgesundheitsblatt 55: 174-175.

Sass, Hans-Martin. 1983. Reichsrundschreiben 1931: Pre-nuremberg German regulations concerning new therapy and human experimentation. Journal of Medicine and Philosophy 8 (99): 99-111.

Schleiermacher, Sabine. 1988. Die SS-Stiftung "Ahnenerbe." Menschen als Material für "exakte" Wissenschaft. In Menschenversuche. Wahnsinn und Wirklichkeit, ed. Rainer Osnowski, 70-87. Köln: Volksblatt Verlag.

Schmaltz, Florian. 2005. Kampfstoff-Forschung im Nationalsozialismus. Zur Kooperation von Kaiser-Wilhelm-Instituten, Militär und Industrie. Geschichte der Kaiser-Wilhelm-Gesellschaft im Nationalsozialismus 11. Göttingen: Wallstein Verlag.

Schmaltz, Florian. 2006a. Otto Bickenbach's human experiments with chemical warfare agents at the concentration camp Natzweiler in the context of the SS-Ahnenerbe and the Reichsforschungsrat. In Man, medicine and the state. The human body as an object of government sponsored research in the 20th century, ed. Wolfgang U. Eckart, 139-156. Beiträge zur Geschichte der Deutschen Forschungsgemeinschaft 2. Stuttgart: Steiner.

Schmaltz, Florian. 2006b. Pharmakologische Nervengasforschung an der Militärärztlichen Akademie und an den Universitäten Marburg, Danzig und Leipzig im Zweiten Weltkrieg. In Medizin im Zweiten Weltkrieg, ed. Wolfgang U. Eckart, and Alexander Neumann, 171-194. Paderborn: Schöningh.

Schmaltz, Florian. 2009. Chemical weapons research in National Socialism: The collaboration of the Kaiser Wilhelm institutes with the military and industry. In The Kaiser Wilhelm Society under National Socialism, ed. Susanne Heim, Carola Sachse, and Mark Walker, 312-338. Cambridge: Cambridge University Press.

Schmidt, Gerald. 1985. Ludwig Lendle (1899-1969). In Neue Deutsche Biographie, ed. Historische Kommission bei der Bayrischen Akademie der Wissenschaften, 201-202. Berlin: Duncker \& Humblot.

Schmidt, Ulf. 2007. Karl Brandt: The Nazi doctor. Medicine and power in the Third Reich. London: Continuum. 
Schmidt, Ulf. 2013. Accidents and experiments: Nazi chemical warfare research and medical ethics during the Second World War. In Military medical ethics for the 21st century, ed. Michael L. Gross, and Don Carrick, 225-244. Farnham, Surrey: Ashgate.

Schuder, Werner. 1961. Kürschners deutscher Gelehrten-Kalender 1961. A-N, 9th ed. Berlin: de Gruyter.

Schuder, Werner. 1970. Kürschners Deutscher Gelehrten-Kalender 1970. Berlin: Walter de Gruyter.

Schultz, Gebhard. 2001. Militärisches Sperrgebiet. Die Zitadelle Spandau im Nationalsozialismus. Berlinerische Monatsschrift 7: 51-59.

Spiegelberg, Ulrich, Karl Dierkes, and Hans Bürger-Prinz. 1961. Psychopathologisch-neurologische Schäden nach Einwirkung synthetischer Gifte. Wehrdienst und Gesundheit: Abhandlungen aus Wehrmedizin, Wehrpharmazie und Wehrveterinärwesen. Darmstadt: Wehr und Wissen Verlagsgesellschaft.

Steegmann, Robert. 2005. Struthof. Le KL-Natzweiler et ses kommandos: une nébuleuse concentrationnaire des deux côtés du Rhin, 1941-1945. Strasbourg: Nuée bleue.

Steegmann, Robert. 2010. Das KZ Natzweiler-Struthof und seine Außenkommandos an Rhein und Neckar 1941-1945. Berlin: Metropol.

Szöllösi-Janze, Margit. 1994. Von der Mehlmotte zum Holocaust. Fritz Haber und die chemische Schädlingsbekämpfung während und nach dem Ersten Weltkrieg. In Von der Arbeiterbewegung zum modernen Sozialstaat. Festschrift für Gerhard A. Ritter zum 65. Geburtstag, ed. Jürgen Kocka, 658-682. München: Saur.

Trunk, Achim. 2011. Die todbringenden Gase. In Neue Studien zu nationalsozialistischen Massentötungen durch Giftgas. Historische Bedeutung, technische Entwicklung, revisionistische Leugnung, eds. Günter Morsch, and Bertrand Perz, 23-49. Berlin: Metropol Verlag.

Uhlmann, Angelika. 2011. August Hirt und seine Mitarbeiter Kiesselbach, Wimmer und Mayer. Die Karrieren vor der Reichsuniversität Straßburg. Revue d'Allemagne et des Pays de Langue Allemande 43(3): 333-340.

Uhlmann, Angelika, and Andreas Winkelmann. 2015. The science prior to the crime. August Hirt's career before 1941. Annals of Anatomy 204: 118-126.

Wirth, Wolfgang. 1936. Über die Wirkung kleinster Phosgenmengen. Naunyn-Schmiedebergs Archiv für Pathologie und experimentelle Pharmakologie 181: 198-206.

Witkowski, Józef, and Aleksandra Rudy. 1987. Gaz bojowy tabun a podobóz Dyhernfurth. Przegląd Lekarski 34 (1): 131-142.

Woelk, Wolfgang. 2003. Der Pharmakologe und Toxikologe Wolfgang Wirth (1898-1996) und die Giftgasforschung im Nationalsozialismus. In Nach der Diktatur. Die Medizinische Akademie Düsseldorf nach 1945, eds. Wolfgang Woelk, Frank Sparing, Karen Bayer, and Michael G. Esch, 269-287. Essen: Klartext-Verlag.

Wojak, Irmtrud. 1999. Das "irrende Gewissen" der NS-Verbrecher und die deutsche Rechtssprechung. Die "jüdische Skelettsammlung" am Anatomischen Institut der "Reichsuniversität Straßburg." In "Beseitigung des jüdischen Einflusses..." Antisemitische Forschung, Eliten und Karrieren im Nationalsozialismus, ed. Fritz-Bauer-Institut, 101-130. Jahrbuch 1998/99 zur Geschichte und Wirkung des Holocaust. Frankfurt, New York: Campus Verlag. 
Open Access This chapter is licensed under the terms of the Creative Commons Attribution-NonCommercial 2.5 International License (http://creativecommons.org/licenses/by-nc/ $2.5 /$ ), which permits any noncommercial use, sharing, adaptation, distribution and reproduction in any medium or format, as long as you give appropriate credit to the original author(s) and the source, provide a link to the Creative Commons license and indicate if changes were made.

The images or other third party material in this chapter are included in the chapter's Creative Commons license, unless indicated otherwise in a credit line to the material. If material is not included in the chapter's Creative Commons license and your intended use is not permitted by statutory regulation or exceeds the permitted use, you will need to obtain permission directly from the copyright holder.

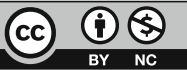

